Georgia State University

ScholarWorks @ Georgia State University

\title{
Medicaid Coverage across the Income Distribution under the Affordable Care Act
}

\author{
Charles J. Courtemanche \\ Georgia State University, ccourtemanche@gsu.edu \\ James Marton \\ Georgia State University, marton@gsu.edu \\ Aaron Yelowitz \\ University of Kentucky, aaron@uky.edu
}

Follow this and additional works at: https://scholarworks.gsu.edu/uwrg_workingpapers

\section{Recommended Citation}

Courtemanche, Charles J.; Marton, James; and Yelowitz, Aaron, "Medicaid Coverage across the Income Distribution under the Affordable Care Act" (2019). UWRG Working Papers. 130.

https://scholarworks.gsu.edu/uwrg_workingpapers/130

This Article is brought to you for free and open access by the Usery Workplace Research Group at ScholarWorks @ Georgia State University. It has been accepted for inclusion in UWRG Working Papers by an authorized administrator of ScholarWorks @ Georgia State University. For more information, please contact scholarworks@gsu.edu. 


\section{W. J. Usery Workplace Research Group Paper Series}

Working Paper 2019-8-3

August 2019

\section{Medicaid Coverage across the Income Distribution under the Affordable Care Act}

Charles Courtemanche University of Kentucky

James Marton

Georgia State University

Aaron Yelowitz

University of Kentucky

This paper can be downloaded at: http://uwrg.gsu.edu

GeorgaState University

ANDREW YOUNG SCHOOL 


\title{
Medicaid Coverage across the Income Distribution under the Affordable Care Act
}

\author{
Charles Courtemanche \\ Department of Economics \\ University of Kentucky \\ Lexington, $\mathrm{KY}$ \\ National Bureau of Economic Research \\ Institute of Labor Economics \\ courtemanche@uky.edu \\ James Marton \\ Department of Economics \\ Andrew Young School of Policy Studies \\ Georgia State University \\ Atlanta, GA \\ marton@gsu.edu \\ Aaron Yelowitz" \\ Department of Economics \\ University of Kentucky \\ Lexington, KY \\ aaron@uky.edu
}

\begin{abstract}
This chapter examines trends in Medicaid enrollment across the income distribution after the ACA's Medicaid expansion. Using data from the American Community Survey between 2012 and 2017, we compare Medicaid coverage over time in 9 states that expanded Medicaid in 2014 with no previous expansion for able-bodied, working-age adults with 12 states that had not expanded Medicaid by 2019 and also had no previous expansion for such adults. A difference-in-differences model is used to formalize this comparison. Similar to many previous studies, we find that Medicaid coverage increased dramatically for income-eligible adults under $138 \%$ of the federal poverty level (FPL). In addition, we show that Medicaid participation increased by 3.0 percentage points for those with incomes above $138 \%$ of the FPL from a pre-ACA baseline of $2.7 \%$ among this group. While we cannot say with certainty why these individuals were able to participate in Medicaid, we offer several potential explanations that should be the subject of future work. For example, it is possible that the ACA Medicaid expansions were administered differently at the state or local level than federal rules would require, similarly to differences between effective tax rates and statutory tax rates in many transfer programs.
\end{abstract}

Keywords: Medicaid, Affordable Care Act, Effective Tax Rates, Health Care Finance

\footnotetext{
${ }^{*}$ Corresponding Author Address: Department of Economics, 225H Gatton Business \& Economics Building, University of Kentucky, Lexington, KY, 40506-0034. Email: aaron@uky.edu.
} 


\section{INTRODUCTION}

Large gains in health insurance coverage were documented early in the rollout from the main components of the Affordable Care Act (ACA) in 2014 (Gruber and Sommers 2019). As originally envisioned in 2010, the ACA aimed to provide robust Medicaid coverage across all states for the poor, and vibrant state-run exchanges with private coverage for those who were more affluent. The intent was to provide different sources of health insurance coverage and different subsidies based on a person’s economic circumstances. Lower-income individuals were meant to get larger subsidies. Medicaid generally provides more heavily subsidized coverage in comparison to Marketplace coverage and was targeted to those with incomes under $138 \%$ of the federal poverty level (FPL). Higher-income individuals were meant to get smaller subsidies. Private coverage, with less generous subsidies, was targeted to those with incomes between $138 \%$ and $400 \%$ of the FPL. While subsidized Marketplace coverage was made available nationally, the Supreme Court ruled in 2012 that the Medicaid expansion was optional for states. As a result, only 27 states (including the District of Columbia) expanded Medicaid in 2014 (Courtemanche et al. 2017). These new sources of subsidized coverage, along with other reforms to the non-group insurance market (such as community rating, guaranteed issue, and minimum coverage requirements) and the individual mandate represent the major 2014 components of the ACA.

Among states opting to expand Medicaid in 2014, the coverage gains in Kentucky were particularly noteworthy. Kentucky experienced the largest percentage point gain in insurance coverage out of all the states in 2014, primarily from increases in Medicaid enrollment (Courtemanche, Marton, and Yelowitz 2016). These gains received national attention. Artiga, Tolbert, and Rudowitz (2016) argued that "Kentucky has had one of the most successful ACA 
implementation experiences among states.” Rosenbaum, Schmucker, and Rothenberg (2016) noted that "among states that have implemented the Affordable Care Act's Medicaid expansion, Kentucky has been singular in its success.” Atkin and Israel (2015) call Kentucky “the nation’s most unlikely Obamacare success story.” A state-commissioned study showed that Kentucky’s Medicaid enrollment exceeded expectations (Deloitte 2015). Remarkably, the report notes that first-year Medicaid expansion enrollment in Kentucky exceeded estimates of the entire pool of potentially eligible enrollees. Yelowitz (2016) found that coverage gains across the income distribution in Kentucky did not always conform to predictions based on self-reports of income in the American Community Survey (ACS) and programmatic rules. Specifically, 38\% of new adults enrolled in Medicaid in Kentucky in 2014 - roughly 73,000 adults - appeared to be income-ineligible, with the vast majority instead qualifying for subsidized private coverage through the Marketplace.

The purpose of this chapter is to examine the impact of the ACA across the income distribution in multiple states, as opposed to focusing on one state, over the first four years of the rollout. Thus our findings contribute to the literature on the impact of the ACA broadly and the literature on the initial implementation of the ACA more specifically. Although many studies show the ACA's success in terms of reducing the number of uninsured individuals, a more nuanced definition of success is whether the ACA was carried out in the way it was intended. The intent was to provide different sources of health insurance coverage based on a person's economic circumstances. Contrary to this intent, our findings here suggest that many consumers who were seemingly eligible for private coverage instead enrolled in Medicaid. There are several other examples of the implementation of the ACA not playing out as intended. As described in Gruber and Sommers (2019), some of the original ACA provisions never became law, such as a 
new program for long-term care insurance (the ill-fated CLASS Act), and others have been repeatedly delayed, such as the "Cadillac Tax" on high-cost employer insurance plans. ${ }^{1}$

Using data from the American Community Survey between 2012 and 2017, we examine 21 states where alternative routes for higher-income, abled-bodied, working-age adults to qualify for Medicaid were essentially non-existent prior to the implementation of the ACA in 2014. Of these 21 states, 9 of them implemented full Medicaid expansions to 138\% of the FPL in 2014, while 12 of them never implemented expansions (as of 2019). Our analysis goes through 2017, allowing us examine whether or not the impact of the ACA across the income distribution varied over time. We compare insurance changes among working-age adults from these two sets of states over time using a difference-in-differences regression framework.

We find that the 2014 Medicaid expansions led to a 3.0 percentage point increase in Medicaid enrollment among working-age adults with incomes at or above $138 \%$ of the FPL, a sizable effect from a baseline rate of $2.7 \%$. This translates into approximately 522,000 seemingly income-ineligible enrollees across the 9 states, and $47 \%$ of the entire gain in insurance coverage for these relatively higher income adults. In addition, this enrollment effect persists for individuals relatively far from the Medicaid threshold of 138\% of the FPL, albeit with smaller baseline participation and marginal effects. The impact of the Medicaid expansions grows over time, with impacts two to three times as large in 2017 as 2014. Many seemingly incomeineligible working-age adults in expansion states enroll in Medicaid rather than the subsidized private, Marketplace coverage.

\footnotetext{
${ }^{1}$ Several other examples illustrate concerns with carrying out the ACA's provisions as intended. The ACA was supposed to facilitate voter registration by interacting with the "motor voter law", yet "the Obama administration didn't include voter registration services in the ACA federal exchanges even though it acknowledges that stateoperated exchanges must comply with the NVRA.” See https://thehill.com/blogs/congress-blog/theadministration/258610-how-obamacare-curtails-voter-registration . Rules finalizing menu labeling in Section 4205 of the ACA were crafted in 2013, yet the regulations on calorie counts were not implemented until 2018.
} 
While we cannot say with certainty why these individuals were able to participate in Medicaid, we offer several potential explanations that should be explored further in future work. One possible reason - echoed in longstanding literature on effective tax rates in welfare programs (Ziliak 2007) - is that the way ACA rules are enforced in states or localities differ from formal federal policy. In practice, issues of prospectively forecasting income for the next calendar year along with anticipating possible deductions in order to compute modified adjusted gross income (MAGI) could lead to income-ineligible individuals receiving Medicaid instead of Marketplace coverage. It is also possible that these findings are attributable to measurement error in either insurance coverage or income in the ACS.

\section{INSTITUTIONAL BACKGROUND}

Although the intent of the ACA is to provide near-universal health insurance coverage, the rules impact some subgroups more than others. Neither the elderly nor children should be dramatically affected by the ACA (Courtemanche et al. 2017, Courtemanche et al. 2018a, Courtemanche et al. 2018b, Courtemanche et al. 2019a, Courtemanche et al. 2019b). Virtually all elderly had coverage through Medicare (perhaps with supplemental coverage from other sources). In 2013, 98\% of elderly had insurance coverage, with 94\% having government coverage (Smith and Medalia 2014). Children tend to be covered at higher rates than workingage adults, because comprehensive safety net programs (implemented long before the ACA) lead to fairly high insurance coverage rates. In 2013, 93\% of children had insurance coverage, with 41\% receiving government health insurance. Medicaid and Children’s Health Insurance Program (CHIP) expansions from the 1980s and 1990s allowed children with household incomes under certain multiples of the FPL to obtain public coverage at minimal cost regardless of family 
structure (Yelowitz 1995). Under Medicaid, newborns were eligible up to 185\% of the FPL, children aged 1 to 5 were eligible up to 133\% of the FPL, and children aged 6 to 18 were eligible up to $100 \%$ of the FPL. Many states expanded considerably higher than these minimums through CHIP, often to 200\% of the FPL or higher. Children in families covered under standalone CHIP programs may pay monthly premiums which in turn could affect enrollment (Marton 2007; Kenney et al. 2007a, 2007b; Marton, Ketsche, and Zhou 2010; Marton, Searcy, and Ghandhi 2010; Marton and Talbert 2010). Children in more affluent households usually had insurance through other sources, such as employer coverage through a parent's plan. The ACA's individual mandate certainly compelled some already-eligible families to take-up Medicaid for their children who had been uninsured but “conditionally covered” (Marton and Yelowitz 2015).

We expect the largest impacts of the ACA on working-age adults, where working-age is defined as ages 19 to 64 . Prior to the ACA, the main avenue for working-age adults to obtain health insurance was through private, employer-sponsored health insurance (ESHI). In 2013, $82 \%$ of working-age adults had insurance coverage, with $68 \%$ having private coverage (Smith and Medalia 2014). The non-group (individual) market was very small prior to the ACA. A small percentage of individuals involved with the armed forces obtained private insurance through the military, called Tricare. In many states, able-bodied, childless, working-age adults did not qualify for Medicaid. Medicaid was generally restricted to narrow categories of adults. Pregnant women with incomes below 185\% of the FPL were eligible for Medicaid. The disabled could potentially qualify for Medicaid through SSI, with a national income limit of approximately $77 \%$ of the FPL, or they may qualify for Medicare after two years on disability insurance; approximately 57\% of disabled adults received government health insurance in 2013. Parents or caretakers could qualify for Medicaid, with income thresholds as high as 57\% of the FPL (Kaiser 
Family Foundation 2013). In addition, foster care children up to age 26, individuals in the Breast and Cervical Cancer Treatment Program, the Medically Needy (Spend Down) Program, the Transitional Medical Assistance program, and the Nursing Facility Services program also received Medicaid. ${ }^{2}$

The 2014 rollout of the main components of the ACA dramatically changed opportunities for working-age adults. The ACA provided a number of reforms, primarily to the non-group (individual) market and to the Medicaid program. As discussed in Courtemanche et al. (2017), 27 states (including the District of Columbia) expanded their Medicaid programs to $138 \%$ of the FPL in the beginning 2014. For working-age adults in Medicaid expansion states, the vast majority of uninsured individuals became newly eligible for Medicaid in 2014 if their incomes were below this threshold. Relative to private coverage, Medicaid generally provides more generous subsidies with respect to copayments and deductibles and has no monthly premiums (Marton 2007). In non-expansion states, adults with incomes under 100\% of the FPL can purchase private health insurance via the Marketplace, but do not receive a subsidy (i.e. they do not qualify for the premium tax credit). Insurance is still community rated and guaranteed issue, thereby providing implicit subsidies to those with high medical expenses. Adults in nonexpansion states with incomes of $100 \%$ to $138 \%$ of the FPL can purchase a highly subsidized Marketplace plan. ${ }^{3}$

Importantly, working-age adults with incomes at or above $138 \%$ of the FPL were generally not eligible for Medicaid. In all states, adults with incomes of $138 \%$ to $400 \%$ of the FPL are eligible to purchase private, non-group health insurance via the Marketplace, with a

\footnotetext{
${ }^{2}$ See Palmer et al. (2017) for additional details about eligibility for Medicaid through foster care.

${ }^{3}$ No individual mandate exists for this group; consumers can claim a coverage exemption even though some privately subsidized plans involve virtually no cost to the consumer. See https://www.irs.gov/pub/irs-pdf/i8965.pdf, p. 3.
} 
sliding-scale subsidy from the premium tax credit. Various cost-sharing provisions from the Marketplace plans are less generous once income exceeds $250 \%$ of the FPL. Those with incomes above $400 \%$ of the FPL can purchase unsubsidized insurance from the Marketplace (or pay the penalty associated with the individual mandate). For further discussion on which parts of the ACA are expected to have the biggest coverage impact on different groups of individuals, see Courtemanche et al. (2017).

\section{DATA}

We use data from the American Community Survey (ACS), conducted by the US Census Bureau, to examine changes in insurance coverage and insurance sources from 2012 to 2017. The ACS is a widely used data source because of its large sample size, mandatory respondent participation, breadth of questions on sources of insurance, focus on contemporaneous coverage, and uniformity of questions over time.

We focus on working-age adults aged 19 to 64 in the 2012 to 2017 ACS, giving us four years of data after the rollout of the biggest pieces of the ACA. We analyze 21 states - which we call "new expanders” and "never expanders.” The new expanders were 9 states that expanded Medicaid in 2014 and had not implemented earlier broad-based Medicaid expansions for adults. They include Arkansas, Kentucky, Michigan, Nevada, New Hampshire, New Mexico, North Dakota, Ohio, and West Virginia. None of these states implemented the expansions early, and none had subgroups (other than pregnant women) eligible for coverage above 138\% of the FPL. The never expanders were 12 states that did not expand by 2019 (and had not implemented earlier expansions). They include Alabama, Florida, Georgia, Kansas, Mississippi, Missouri, North Carolina, Oklahoma, South Carolina, South Dakota, Texas, and Wyoming. In these states, 
the Medicaid income eligibility threshold was between 17 to 54\% of the FPL for adult caretakers in families. For childless adults, none of these states extended eligibility for coverage. As a consequence, all 21 states had weak health insurance safety nets for working-age adults prior to the ACA, and there is little reason to expect increased Medicaid take-up at incomes higher than $138 \%$ of the FPL in any state after the rollout. ${ }^{4}$

The insurance questions in the ACS form the core of the analysis and have both advantages and drawbacks. The focus on current coverage in the ACS leads to less confusion than with other public surveys such as the Current Population Survey (CPS), which asks respondents to recall coverage in the previous calendar year (Klerman et al. 2009). ${ }^{5}$ In addition, the ACS is continuously fielded during the year. One drawback with the public version of the ACS is that the respondent's interview date within the year is unknown. However, virtually all changes from the ACA occurred at the beginning 2014, limiting the need for precise interview timing. As discussed below, this includes the rollout of the Medicaid expansions for almost all of the selected states we consider.

ACS respondents may report more than one source of coverage. In our tables below, we create categories for seven sources of coverage, where the first six sources are defined as having coverage from that source only. The sources are employer-sponsored health insurance (ESHI), non-group (individual), Tricare, Medicaid, Medicare, and VA. The final category is defined as "multiple”, meaning the individual reports coverage in at least two of the coverage sources. In practice, approximately $8 \%$ of the sample reports multiple contemporaneous sources, and this

\footnotetext{
${ }^{4}$ For details on pregnant women / other adults see: https://www.kff.org/medicaid/fact-sheet/where-are-states-todaymedicaid-and-chip/

${ }^{5}$ The ACS asks: "Is this person CURRENTLY covered by any of the following types of health insurance or health coverage plans?” See https://www2.census.gov/programs-surveys/acs/methodology/questionnaires/2014/quest14.pdf
} 
percentage changes very little over the time period. Adding up all seven sources of coverage gives the overall coverage rate.

Several limitations to measuring health insurance coverage with the ACS should be noted. Prior work has shown that private, non-group coverage is overstated in the ACS, both as a sole type of comprehensive coverage and as reported in combination with other coverage types. Substantive differences in individual coverage exist between survey estimates and administrative counts from the National Association of Insurance Commissioners (Abraham, Karaca-Mandic, and Boudreaux 2013). Mach and O’Hara (2011) find that the population that reports non-group health insurance coverage in combination with other sources is small, but it seems to be misreported, especially in combination with employer-based insurance. Our results below reveal gains in non-group coverage were small in Medicaid-expansion states after the reform, and these studies suggest that even those small gains may be overstated.

In addition, the ACS survey instrument does not include any state-specific names for Medicaid, and the survey instrument was not updated to reflect newly available marketplace coverage. Thus, there is concern that ACS respondents may be confused about their coverage type, leading to additional misreporting on household surveys post-2013, after the major ACA provisions were implemented. However, in studying California's 2011 implementation of the Low-Income Health Program (LIHP), Sommers et al. (2016) estimate an increase in net public insurance enrollment of 111,000 with the ACS from the LIHP, which they note "is nearly within the 95 percent confidence interval” of the 200,000 enrollee increase in administrative data sources. They conclude, “The ACS can be used for reasonably precise and valid estimates of within-state changes in coverage, both at the population level and for subgroups that likely could not be studied with alternative surveys containing much smaller sample sizes.” 
We first examine changes in coverage. In the calculations below, it should be noted that population changes from year-to-year (as well as within income groupings). To allocate gains in coverage to specific sources, we use average population across all years for working-age adults. Our insurance sources (including uninsured and multiple sources) add up to 100\% in each year. We approximate the change (in levels or attributable to a source) by multiplying the percentage point change by average population, or by comparing that change to the percentage point change in the insured population. Table 1 shows health insurance coverage from 2012 to 2017 for the 9 states that expanded Medicaid in 2014. Across these states, total population averaged 22.8 million and insurance coverage increased by 10.4 percentage points from 2012 to 2017, leading to 2.4 million more adults having coverage. Medicaid coverage increased by approximately 1.7 million, translating into approximately $69 \%$ of the total gains. Overall, there were also modest gains from employer coverage and non-group coverage (387,000 and 319,000, respectively), responsible for $16 \%$ and $13 \%$ of the gains, respectively. Employer coverage could increase due to improving economic conditions, the individual mandate, and the ACA's employer mandate (effective 2015). Non-group (individual) insurance should increase due to the establishment of subsidized Marketplace coverage. There was modest growth in Medicare coverage and a modest reduction in Tricare and VA coverage. ${ }^{6}$

We break out the 22.8 million adults in these 9 states between 2012 and 2017 into 5.4 million with incomes under $138 \%$ of the FPL, 4.3 million with incomes between $138 \%$ to $249 \%$ of the FPL, and 13.1 million with incomes at or above $250 \%$ of the FPL. For poor Medicaideligible adults ( $<138 \%$ of the FPL), Medicaid is responsible for $92 \%$ of the insurance gains from 2012 to 2017. Overall coverage grew in these 9 states by 21.3 percentage points overall.

\footnotetext{
${ }^{6}$ Chatterji, Liu, and Yörük (2019) find that the ACA's dependent care provision reduced the probability that young adults are sponsors on Tricare health insurance plans.
} 
Approximately 1.1 million low-income adults gained Medicaid. There were small and offsetting changes in employer and non-group coverage.

For the near-poor (138\% to $249 \%$ of the FPL) in these 9 states, one would expect that many of the 4.3 million would not be Medicaid eligible during the year, but would be eligible for highly subsidized private coverage through the Marketplace. Insurance coverage increased by 13.7 percentage points among this near-poor group in these 9 states. Overall, the descriptive estimates would suggest that 458,000 in this group (that are seemingly income-ineligible) gained Medicaid coverage, representing $78 \%$ of the overall gain in coverage. Gains in non-group individual coverage were one-fifth as large - around 103,000 adults - in these 9 states between 2012 and 2017.

Given that this might be explained to some degree by income variation around the $138 \%$ of the FPL cut-off, we also examine those with incomes at or above $250 \%$ of the FPL. For the 13.1 million non-poor (i.e. income $\geq 250 \%$ of the FPL) in these 9 states, coverage grew by 4 percentage points, translating into around 525,000 more insured overall. Even among this higher income group, Medicaid grew by 342,000, and represented 65\% of the change in coverage. Gains in non-group individual coverage were one-half as large - around 157,000 adults. Employer coverage grew modestly, and there were small changes in other categories between 2012 and 2017.

To summarize the main findings of table 1 , we are focusing on the 9 states that expanded their Medicaid program via the ACA in 2014 and previously lacked a deep safety net in terms insurance coverage for non-elderly adults above 138\% of the FPL. Overall, more than 2.4 million non-elderly adults gained coverage in these 9 states between 2012 and 2017; a 10.4 percentage point increase. Medicaid coverage alone increased 7.2 percentage points, or 
approximately 1.7 million non-elderly adults. Of these, around 800,000 individuals (around 43\%) appeared to gain Medicaid coverage for which they were seemingly income-ineligible. In principle, many would be eligible for subsidized private coverage through the Marketplace.

Table 2 reports changes in health insurance coverage over time for the 12 states that did not expand Medicaid via the ACA by 2019. Total population averaged 56.8 million and insurance coverage increased by 7.1 percentage points, leading to approximately 4.0 million more working-age adults having coverage between 2012 and 2017. Medicaid coverage increased by 227,000 ( 0.4 percentage points), translating into approximately $6 \%$ of the total gains over these six years. Overall, there were also larger contributions from employer coverage and nongroup coverage, responsible for $52 \%$ and $45 \%$ of the insurance gains, respectively. Employer coverage grew by 3.7 percentage points, and non-group coverage grew by 3.2 percentage points, translating into 2.1 million and 1.8 million newly covered, respectively.

Within these 12 non-expansion states, we break out the average population of 56.8 million into 13.7 million with incomes under $138 \%$ of the FPL, 11.5 million with incomes between $138 \%$ to $249 \%$ of the FPL, and 31.6 million with incomes at or above $250 \%$ of the FPL, as we did with the expansion states. For poor working-age adults in non-expansion states (i.e. with incomes under $138 \%$ of the FPL), Medicaid is responsible for $18 \%$ of the insurance gains from 2012 to 2017 (versus 92\% in expansion states). Overall insurance coverage grew by 10.2 percentage points (far less than in expansion states), and Medicaid coverage grew by 1.8 percentage points. Approximately 246,000 low-income adults gained Medicaid. There were sizable gains for employer and individual coverage, 2.7 and 4.0 percentage points, translating to gains in coverage of 370,000 and 548,000, respectively. 
For near-poor working-age adults these 12 states, one would expect that many of the 11.5 million would not be Medicaid eligible, yet many would be eligible for subsidized Marketplace plans. Insurance coverage increased by 9.4 percentage points (again, smaller than for this same group in expansion states), and Medicaid coverage increased by 1.2 percentage points (dramatically lower than the 10.7 percentage point gain in expansion states). Overall, the estimates would suggest nearly 1.1 million working-age adults in this near-poor group gained coverage between 2012 and 2017. Of these, 137,000 gained Medicaid coverage, representing 13\% (rather than 78\%) of the overall gain in coverage, though they are seemingly incomeineligible for Medicaid. Gains in non-group individual coverage were more than four times as large - around 631,000 adults.

For the 31.6 million non-poor working-age adults in these 12 non-expansion states, coverage grew by 2.9 percentage points (versus 4.0 percentage points for this group in the 9 expansion states), translating into around 917,000 more insured. Among this income group, Medicaid coverage grew by 158,000, and represented 17\% (rather than 65\% in the 9 expansion states) of the change in coverage. Gains in non-group individual coverage were four times as large - around 632,000 adults. None of these states expanded Medicaid by 2019, and none had significant safety net insurance coverage for non-elderly childless adults.

Overall, the descriptive coverage estimates in table 2 for the non-expansion states find approximately 4.0 million non-elderly adults gained some form of insurance coverage between 2012 and 2017. Of these, 227,000 (6\%) gained coverage via Medicaid. Although gains in Medicaid were very small in non-expansion states compared to expansion states, among those gaining coverage via Medicaid, 54\% appeared to be income-ineligible. 


\section{METHODS}

In this section we describe a difference-in-differences model to formalize the comparison in changes in Medicaid coverage across the income distribution between the 9 expansion states from table 1 and 12 non-expansion states from table 2 before versus after the ACA Medicaid expansion. The DD specification takes the form:

$$
M_{i s t}=\beta_{0}+\beta_{1}\left(\text { MEDICAID }_{s} * \text { POST }_{t}\right)+\beta_{2} \text { POST }_{t}+\beta_{3} \text { MEDICAID }_{s}+\beta_{4} X_{i s t}+\varepsilon_{i s t}
$$

where $M_{i s t}$ is an indicator for whether individual $i$ living in state $s$ had Medicaid coverage in year t, MEDICAID indicates whether state $s$ participated in the ACA's Medicaid expansion in 2014, $\mathrm{POST}_{t}$ indicates whether time $t$ is in the post-treatment period (2014 or later), $X_{i s t}$ is a set of individual-level controls, and $\varepsilon_{i s t}$ is the error term. Standard errors are robust to heteroskedasticity and clustering by state. All models use person-weights provided in the ACS. The individual controls in $X_{i s t}$ include the respondent's age, gender, education, race/ethnicity, difficulty with English, citizenship, foreign born indicator, marital status, changes in family structure, military service, disability, annual work hours, and receipt of various income sources. In some specifications we include location and year fixed effects (denoted $\alpha_{a s}$ and $\tau_{t}$, respectively), in which case we do not separately include the $M E D I C A I D_{s}$ and $P O S T_{t}$ dummies. These location fixed effects control for the individual's public-use microdata area (PUMA) of residence. There are 985 PUMAs (nested within states) represented by the individuals in our sample from our 21 states of interest in the ACS.

The key coefficient of interest is $\beta_{1}$, which represents the average effect of the Medicaid expansion on Medicaid coverage for working-age adults in expansion states. The coefficient estimate has a causal interpretation under the assumption that, conditional on the other covariates, changes in Medicaid coverage post 2013 would have been the same in expansion and 
non-expansion states if the Medicaid expansion had not occurred. Figure 1 plots the trends in Medicaid coverage over time between the 9 expansion and 12 non-expansion states in our sample. For all income groups, the trends in coverage prior to expansion in 2014 look remarkably similar.

To more formally test the identifying assumption of our difference-in-differences model, we estimate an event study model given by:

$$
\begin{gathered}
M_{i s t}=\gamma_{0}+\gamma_{1} \sum_{t=2012}^{2017}\left(M_{E D I C A I D} * Y E A R_{t}\right)+\gamma_{2} \text { MEDICAID }_{s}+\gamma_{3} X_{i s t}+\alpha_{s}+\tau_{t} \\
+\varepsilon_{i s t}
\end{gathered}
$$

Here we replace the $\mathrm{POST}_{t}$ indicator with a vector of individual year indicators, with 2013 being the reference year. If the model is valid, we would expect the interaction of the year indicator for 2012 and the Medicaid expansion indicator to be statistically insignificant, or at least for its coefficient estimate to be small relative to those from the post-treatment years. This specification also allows us to see the year over year impact of the ACA Medicaid expansion by examining the coefficient estimates for the interactions of the year indicators for 2014, 2015, 2016, and 2017 with the Medicaid expansion indicator.

\section{RESULTS}

Table 3 examines the impact of Medicaid expansions on Medicaid coverage among adults across the income distribution. As with the earlier tables, Medicaid coverage is defined as the individual having that source as a unique form of coverage (rather than having multiple sources). Overall, there were 1,094,667 working-age adults aged 19 to 64 with incomes below $138 \%$ of the FPL (or missing), and 3,440,670 adults with incomes at or above $138 \%$ of the FPL 
in the ACS sample. In principle, if the ACS data accurately measured income and health insurance coverage sources and the Medicaid statutory rules were fully enforced, we would not expect any Medicaid participation among higher income adults. In practice, Medicaid coverage was reported to be $2.7 \%$ for higher income adults (in 2012/2013, prior to the rollout; coverage was $18.2 \%$ for lower-income adults). This suggests that other avenues may exist to qualify for Medicaid for higher-income adults. As a check on the results, we also restrict the sample to 2,906,015 higher-income respondents who do not report a birth in the past year, disability, or receipt of income from SSI, Social Security, or public assistance. The baseline participation rate in $2012 / 2013$ is much lower at $1.4 \%$.

Columns 1, 3, 5, and 7 of Table 3 estimate DD models without additional controls for the full sample of income-eligible adults, ineligible adults, as well as those who are near the Medicaid income threshold (138 to 249\% of the FPL), and those who are far from the threshold (250\% of the FPL or higher). Columns 2, 4, 6, and 8 include individual covariates, as well as locality and year fixed effects.

In the first panel focusing on the income-eligible sample, column 1 reveals baseline Medicaid participation of 18.2\%. The Medicaid expansions (in the 9 states) increased participation by 13.6 percentage points, with similar results when more detailed covariates are included in column 2.

Column 3 reveals baseline Medicaid participation among the ineligible population prior to the ACA reforms was 2.7\%, and the Medicaid expansions increased participation by an additional 3.0 percentage points (standard error $=0.4$ ). Including individual characteristics some of which are highly predictive of Medicaid participation - has very little impact on the rise in participation from the pre- to post-period; column 4 reveals expansions increase participation 
by 3.0 percentage points among ineligibles. Some individual characteristics - especially the presence of SSI income, public assistance income, social security, or disability status - are extremely important determinants of Medicaid participation for this group of seemingly ineligible adults. These factors are suggestive of alternative pathways to qualify for Medicaid among working-age adults, namely via the pregnancy expansions, disability programs, and welfare programs. Other factors that are linked to sizable increases in Medicaid participation include lack of a high school diploma and being a recent mover. The second panel focuses on the subset of respondents who are highly unlikely to qualify for Medicaid through categorical eligibility. Although the pre-ACA participation rate was just $1.4 \%$, the coefficient estimates are nearly as large as the full sample with incomes at or above $138 \%$ of the FPL. Virtually all of the increase in participation for income-ineligible adults is coming from those with no obvious path to qualify for Medicaid.

Returning to the first panel, the next two groupings separate out individuals into those who might be considered close to the Medicaid threshold (138\% to $249 \%$ of the FPL), and those who are far from it ( $\geq 250 \%$ of the FPL). To the extent that income is volatile during the year, one might expect that those whose incomes were close to the threshold may have qualified for at least part of the year, and may currently have Medicaid coverage. In contrast, it would be far less likely that those with particularly high incomes would qualify, even with volatility. Focusing on the DD results, we observe increases of 7.2 and 1.6 percentage points, respectively, for those near and far from the Medicaid eligibility threshold. Excluding those who may be categorically eligible leads to nearly identical marginal effects of 7.0 and 1.4 percentage points (from baseline Medicaid participation rates of $3.6 \%$ and $0.7 \%$ for those near and far from the threshold). 
Tables 4 and 5 present two versions of our event study specification, with table 4 reporting event study results for the full sample, while table 5 excludes those who might be categorically eligible. Among income-eligible adults, the event study specification shows the marginal impact of the expansions was more than twice as large in 2017 as in 2014 in column 1. For the income-ineligible population, Medicaid participation grew over time as well. The marginal impacts either doubled or tripled from 2014 to 2017, depending on the sample and specification. For example, among the sample that excludes categorically eligible individuals with income at or above $250 \%$ of the FPL (Table 5, column 8), the marginal impact increased from 0.7 percentage points in 2014 to 1.8 percentage points in 2017, from a baseline participation rate of $0.7 \%$. The "placebo" coefficients for the 2012 interaction are sometimes statistically significant, but in all cases much smaller than the magnitudes for the post-treatment interactions.

In summary, there is strong evidence that Medicaid participation increased for groups for whom Medicaid was not intended to be the source of insurance coverage. Neither excluding those who might be categorically eligible, nor focusing on those whose income was far from the threshold alters the fundamental results. The estimated program effect grows over time. The estimated magnitudes from the DD analysis in Table 3 are non-trivial. If the coefficient estimates from the DD analysis are applied to the full sample of ineligible adults in the 9 expansion states (from Table 1), approximately 308,000 working-age adults with incomes between 138\% to 249\% of the FPL joined Medicaid due to the ACA expansions, while 223,000 adults with incomes at or above $250 \%$ of the FPL joined due to the expansions. 


\section{DISCUSSION}

As mentioned above, we find large impacts of the ACA Medicaid expansion on Medicaid coverage among working-age adults with incomes below 138\% of the FPL. In addition, perhaps somewhat surprisingly, we also find increases in Medicaid coverage among adults with income between 138 and $250 \%$ of the FPL, as well as those with income at or above $250 \%$ of the FPL. We conclude this chapter with some discussion of potential explanations for these findings, which should be the focus of future work.

One potential explanation for these findings could be mismeasurement of either income or insurance coverage in the ACS. With respect to insurance coverage, the fact that healthcare.gov is designed to be a one-stop-shop for insurance coverage that routes applicants to either Marketplace or Medicaid coverage as appropriate could lead to some confusion in terms of the applicant's final source of coverage. The fact that multiple private insurance companies sell both Marketplace and Medicaid managed care plans may also contribute to this confusion. In addition, while the ACS health insurance survey question clearly asks individuals to self-report their current sources of coverage, survey respondents may answer the question in different ways, such as their longest source of coverage during the year. Of course, both of these explanations may be just as likely to lead to individuals under-reporting Medicaid coverage as over-reporting it.

In terms of income, the ACS asks individuals to self-report income from a variety of sources over the previous 12 months. All major household surveys have been found to have some degree of measurement error in income, and the ACS is no exception (Moore, Stinson, and Welniak, Jr. 1997; Czajka 2012; Czajka and Denmead 2014). Comparisons of income measures constructed using survey responses with administrative records show that surveys tend to 
understate total income for most sources. It is not clear if under-reporting in a survey context such as the ACS would carry over into the application process for transfer programs such as Medicaid, but it may be possible given that in both cases individuals are reporting income data to government. It could also be the case that individuals may be basing their survey answers on forecasts of future income rather than a recounting of income over the previous 12 months or may not recall accurately all sources of income. While under-reporting seems more common, if some of these reasons lead individuals to overstate their income in the ACS, then they may appear to be income-ineligible for Medicaid.

A related possibility is that people have trouble forecasting their income when determining their eligibility for ACA coverage. For example, an individual applying during the open enrollment period in late 2013 would forecast their 2014 income, and Marketplace subsidies such as the premium tax credit would be advanced ahead of time based on their forecast (Yelowitz 2016). If an individual under-forecasts their income, then they may qualify for Medicaid coverage despite ultimately realizing a higher level of income during the year.

Even with the possibility of measurement error in insurance coverage, income, or noisy forecasting, it is also possible that the ACA legislative rules are simply not being carried out as intended. The fact that the marginal effect of the Medicaid expansions increases over time suggests that instead of noisy forecasting, consumers may be deliberately under-reporting their income. For decades, prominent researchers have found that the "effective tax rate" on income to be far below the statutory level specified by program rules for welfare programs like Aid to Families with Dependent Children, primarily from income that is disregarded in eligibility calculations (Ziliak 2007). One possible reason for this divergence could be caseworker error or discretion. Moffitt (1979) notes that caseworkers might make mistakes when applying complex 
regulations to calculating benefits. Favorable errors that understate income are less likely to be pointed out by the welfare participant (McKinnish, Sanders, and Smith 1999). Edin and Jencks (1992) emphasize the role of caseworker discretion, noting that caseworkers often knew about clients' unreported supplemental income, but choose not to pursue the issue with them. Both issues - error and discretion - could arise in the ACA context. In 2015, there were more than 4,600 assister programs helping approximately 5.9 million consumers (Pollitz, Tolbert, and Ma 2015), and were funded through a variety of mechanisms. These programs helped an estimated 630,000 consumers apply for coverage. The assister programs employed 30,400 full time equivalent staff and volunteers. Given the magnitude and complexity of the ACA rollout, both the skills and motivations of such workers in terms of furthering their clients' interests will surely vary, and could plausibly explain some of our findings. 


\section{REFERENCES}

Abraham, Jean M., Pinar Karaca-Mandic, and Michel Boudreaux. 2013. "Sizing Up the Individual Market for Health Insurance: A Comparison of Survey and Administrative Data Sources.” Medical Care Research and Review 70(4): 418-33.

Artiga, Samantha, Jennifer Tolbert, and Robin Rudowitz. 2016. "Implementation of the ACA in Kentucky: Lessons Learned to Date and the Potential Effects of Future Changes.” Kaiser Family Foundation Issue Brief, Kaiser Family Foundation, April. http://files.kff.org/attachment/issue-brief-implementation-of-the-aca-in-kentucky-lessonslearned-to-date-and-the-potential-effects-of-future-changes.

Atkin, Emily, and Josh Israel. 2015. "Kentucky Is Obamacare’s Undeniable Success Story. This Man Is Trying to Burn It All Down.” ThinkProgress, September 14. https://thinkprogress.org/kentucky-is-obamacares-undeniable-success-story-this-man-istrying-to-burn-it-all-down-56c7d60933ac\#.olltoebkd.

Chatterji, Pinka, Xiangshi Liu, and Barış K. Yörük. 2019. "Effects of the 2010 Affordable Care Act Dependent Care Provision on Military Participation Among Young Adults.” Eastern Economic Journal 45(1): 87-111.

Courtemanche, Charles, James Marton, and Aaron Yelowitz. 2016. "Who Gained Insurance Coverage in 2014, the First Year of Full ACA Implementation?” Health Economics 25(6): 778-84.

Courtemanche, Charles, James Marton, Benjamin Ukert, Aaron Yelowitz, and Daniela Zapata. 2017. "Impacts of the Affordable Care Act on Health Insurance Coverage in Medicaid Expansion and Non-Expansion States.” Journal of Policy Analysis and Management 36(1): 178-210.

Courtemanche, Charles, James Marton, Benjamin Ukert, Aaron Yelowitz, and Daniela Zapata. 2018a. "Early Effects of the Affordable Care Act on Health Care Access, Risky Health Behaviors, and Self - Assessed Health," Southern Economic Journal, 84(3): 660-691.

Courtemanche, Charles, James Marton, Benjamin Ukert, Aaron Yelowitz, and Daniela Zapata. 2018b. "Effects of the Affordable Care Act on Health Care Access and Self-Assessed Health after 3 Years," Inquiry: The Journal of Health Care Organization, Provision and Financing, 55: 1-10.

Courtemanche, Charles, James Marton, Benjamin Ukert, Aaron Yelowitz, and Daniela Zapata. 2019. "Effects of the Affordable Care Act on Health Behaviors after 3 Years," Eastern Economic Journal, 45(1): 7-33. 
Courtemanche, Charles, James Marton, Benjamin Ukert, Aaron Yelowitz, Daniela Zapata, and Ishtiaque Fazlul. 2019. "The Three-Year Impact of the Affordable Care Act on Disparities in Insurance Coverage,” Health Services Research, 54(S1): 307-316.

Czajka, John L. 2012. "Measuring Income Simply: Observations from a Comparative Analysis of Survey Income Data.” Presentation to the Population Health Subcommittee, NCVHS, Mathematica Policy Research, March 9. http://www.ncvhs.hhs.gov/wpcontent/uploads/2014/05/120308p12.pdf.

Czajka, John L., and Gabrielle Denmead. 2014. "Getting More from Survey Income Measures: Empirically-Based Recommendations for Improving Accuracy and Efficiency.” Accessed July 2019. https://s3.amazonaws.com/sitesusa/wpcontent/uploads/sites/242/2014/05/Czajka_2012FC SM_III-D.pdf.

Deloitte Development LLC. 2015. “Commonwealth of Kentucky Medicaid Expansion Report: 2014.” Deloitte Development LLC, February. http://jointhehealthjourney.com/images/uploads/channelfiles/Kentucky_Medicaid_Expansion_One-Year_Study_FINAL.pdf.

Edin, Kathryn, and Christopher Jencks. 1992. “Reforming Welfare.” In Rethinking Social Policy: Race, Poverty, and the Underclass, edited by Christopher Jencks, 204-35. Cambridge: Harvard University Press.

Gruber, Jonathan, and Benjamin D. Sommers. 2019. “The Affordable Care Act's Effects on Patients, Providers and the Economy: What We've Learned so Far.” National Bureau of Economic Research Working Paper 25932, National Bureau of Economic Research, June. http://www.nber.org/papers/w25932.

Kaiser Family Foundation. 2013. “Medicaid Eligibility for Adults as of January 1, 2014.” Kaiser Family Foundation Fact Sheet. Accessed September 2016. https://kaiserfamilyfoundation.files.wordpress.com/2013/10/8497-medicaid-eligibilityforadults-as-of-january-1-2014.pdf.

Kenney, Genevieve, R. Andrew Allison, Julia Costich, James Marton, and Joshua McFeeters. 2007a. "The Effects of Premium Increases on Enrollment in SCHIP Programs: Findings from Three States.” Inquiry 43(4): 378-92.

Kenney, Genevieve, James Marton, Joshua McFeeters, and Julia Costich. 2007b. “Assessing Potential Enrollment and Budgetary Effects of SCHIP Premiums: Findings from Arizona and Kentucky.” Health Services Research 42(6 pt. 2): 2354-72.

Klerman, Jacob A., Michael Davern, Kathleen Call, Victoria Lynch, and Jeanne Ringel. 2009. "Understanding the Current Population Survey's Insurance Estimates and the Medicaid Undercount.” Health Affairs 28(6): 991-1001. 
Mach, Annie, and Brett O’Hara. 2011. "Do People Really Have Multiple Health Insurance Plans? Estimates of Nongroup Health Insurance in the American Community Survey.” SEHSD Working Paper Number 2011-28. Social, Economic, and Housing Statistics Division, United States Census Bureau, January. https://www.census.gov/content/dam/Census/library/workingpapers/2011/demo/SEHSD-WP2011-28.pdf.

Marton, James. 2007. "The Impact of the Introduction of Premiums into a SCHIP Program.” Journal of Policy Analysis and Management 26(2): 261-79.

Marton, James, Patricia Ketsche, and Mei Zhou. 2010. "SCHIP Premiums, Enrollment, and Expenditures: A Two State, Competing Hazard Analysis.” Health Economics 19(7): 77291.

Marton, James, Cynthia S. Searcy, and Jennifer Ghandhi. 2010. "Disparate Effects of CHIP Premiums on Disenrollment for Minorities," in Current Issues in Health Economics, edited by Daniel Slottje and Rusty Tchernis. United Kingdom: Emerald Group.

Marton, James, and Jeffrey Talbert. 2010. "SCHIP Premiums, Health Status, and the Insurance Coverage of Children.” Inquiry 47(3): 199-214.

Marton, James, and Aaron Yelowitz. 2015. "Health Insurance Generosity and Conditional Coverage: Evidence from Medicaid Managed Care in Kentucky." Southern Economic Journal 82(2): 535-55.

McKinnish, Terra, Seth Sanders, and Jeffrey Smith. 1999. "Estimates of Effective Guarantees and Tax Rates in the AFDC Program for the Post-OBRA Period.” Journal of Human Resources 34(2): 312-45.

Moffitt, Robert. 1979. "Cumulative Effective Tax Rates and Guarantees in Low-Income Transfer Programs.” Journal of Human Resources 14(1): 122-9.

Moore, Jeffrey C., Linda L. Stinson, and Edward J. Welniak, Jr. 1997. "Income Measurement Error in Surveys: A Review.” Census Working Paper SM97-05, United States Census Bureau. https://www.census.gov/content/dam/Census/library/workingpapers/1997/adrm/sm97-05.pdf

Palmer, Makayla, James Marton, Aaron Yelowitz, and Jeffrey Talbert. 2017. "Medicaid Managed Care and the Health Care Utilization of Adolescent Foster Children.” Inquiry: The Journal of Health Care Organization, Provision and Financing 54:1-9.

Pollitz, Karen, Jennifer Tolbert, and Rosa Ma. 2015. “2015 Survey of Health Insurance Marketplace Assister Programs and Brokers,” Kaiser Family Foundation Issue Brief, Kaiser Family Foundation, August. https://nationaldisabilitynavigator.org/wpcontent/uploads/resources-links/KFF_2015-survey-marketplace-assister-programs.pdf. 
Rosenbaum, Sara, Sara Schmucker, and Sara Rothenberg. 2016. "Will Kentucky Roll Back Its Medicaid Expansion?” To the Point, The Commonwealth Fund, July 8.

http://www.commonwealthfund.org/publications/blog/2016/jul/will-kentucky-roll-backits-medicaid-expansion.

Smith, Jessica C., and Carla Medalia. 2014. "Health Insurance Coverage in the United States: 2013.” Current Population Reports P60-250, United States Census Bureau, September. https://www2.census.gov/library/publications/2014/demographics/p60-250.pdf.

Sommers, Benjamin D., Kao-Ping Chua, Genevieve M. Kenney, Sharon K. Long, and Stacey McMorrow. 2016. "California’s Early Coverage Expansion under the Affordable Care Act: A County-Level Analysis.” Health Services Research 51(3): 825-45.

Yelowitz, Aaron. 1995. “The Medicaid Notch, Labor Supply and Welfare Participation: Evidence from Eligibility Expansions.” Quarterly Journal of Economics 110(4): 909-39.

Yelowitz, Aaron. 2016. "How Did the ACA Affect Health Insurance Coverage in Kentucky?” Schnatter Institute Working Paper. John H. Schnatter Institute for the Study of Free Enterprise, University of Kentucky, Accessed September. http://isfe.uky.edu/sites/ISFE/files/research-pdfs/Schnatter.2017.Yelowitz.pdf

Ziliak, James. 2007. "Making Work Pay: Changes in Effective Tax Rates and Guarantees in US Transfer Programs, 1983-2002.” Journal of Human Resources 42(3): 619-42. 
Table 1: New Expanders, Coverage for Working-Age Adults

\begin{tabular}{|c|c|c|c|c|c|c|c|c|c|c|c|}
\hline \multirow[b]{2}{*}{ Income bin } & \multirow[b]{2}{*}{ Year } & \multirow[b]{2}{*}{ Population } & \multirow[b]{2}{*}{$\begin{array}{c}\text { Any } \\
\text { coverage }\end{array}$} & \multirow[b]{2}{*}{ Uninsured } & \multicolumn{3}{|c|}{ Private Sources } & \multicolumn{3}{|c|}{ Public Sources } & \multirow[b]{2}{*}{ Multiple } \\
\hline & & & & & ESHI & Non-group & Tricare & Medicaid & Medicare & VA & \\
\hline \multirow[t]{14}{*}{ All } & 2012 & $22,846,118$ & $\begin{array}{c}18,319,724 \\
(26,483)\end{array}$ & $\begin{array}{c}4,526,394 \\
(26,483)\end{array}$ & $\begin{array}{c}12,712,229 \\
(35,496)\end{array}$ & $\begin{array}{c}1,245,129 \\
(17,128)\end{array}$ & $\begin{array}{c}217,383 \\
(7,249)\end{array}$ & $\begin{array}{c}1,802,104 \\
(18,825)\end{array}$ & $\begin{array}{c}344,938 \\
(8,044)\end{array}$ & $\begin{array}{c}148,388 \\
(5,092)\end{array}$ & $\begin{array}{c}1,849,551 \\
(19,840)\end{array}$ \\
\hline & & & $80.2 \%$ & $19.8 \%$ & $55.6 \%$ & $5.5 \%$ & $1.0 \%$ & $7.9 \%$ & $1.5 \%$ & $0.6 \%$ & $8.1 \%$ \\
\hline & 2013 & $22,833,979$ & $\begin{array}{c}18,420,892 \\
(25,656)\end{array}$ & $\begin{array}{c}4,413,087 \\
(25,656)\end{array}$ & $\begin{array}{c}12,745,386 \\
(35,231)\end{array}$ & $\begin{array}{c}1,308,355 \\
(16,797)\end{array}$ & $\begin{array}{c}204,640 \\
(6,711)\end{array}$ & $\begin{array}{c}1,918,004 \\
(17,792)\end{array}$ & $\begin{array}{c}355,518 \\
(7,373)\end{array}$ & $\begin{array}{c}140,927 \\
(5,065)\end{array}$ & $\begin{array}{c}1,748,062 \\
(17,274)\end{array}$ \\
\hline & & & $80.7 \%$ & $19.3 \%$ & $55.8 \%$ & $5.7 \%$ & $0.9 \%$ & $8.4 \%$ & $1.6 \%$ & $0.6 \%$ & $7.7 \%$ \\
\hline & 2014 & $22,834,946$ & $\begin{array}{c}19,588,965 \\
(23,764)\end{array}$ & $\begin{array}{c}3,245,981 \\
(23,764)\end{array}$ & $\begin{array}{c}12,968,409 \\
(33,739)\end{array}$ & $\begin{array}{c}1,540,242 \\
(15,281)\end{array}$ & $\begin{array}{c}193,115 \\
(6,156)\end{array}$ & $\begin{array}{c}2,603,561 \\
(21,102)\end{array}$ & $\begin{array}{c}381,567 \\
(7,972)\end{array}$ & $\begin{array}{c}135,201 \\
(4,658)\end{array}$ & $\begin{array}{c}1,766,870 \\
(15,731)\end{array}$ \\
\hline & & & $85.8 \%$ & $14.2 \%$ & $56.8 \%$ & $6.7 \%$ & $0.8 \%$ & $11.4 \%$ & $1.7 \%$ & $0.6 \%$ & $7.7 \%$ \\
\hline & 2015 & $22,811,536$ & 20,403,388 & 2,408,148 & 12,905,551 & 1,675,035 & 194,350 & 3,244,624 & 388,930 & $\begin{array}{l}115,896 \\
-490)\end{array}$ & $1,879,002$ \\
\hline & & & $(20,177)$ & $(20,177)$ & $(29,436)$ & $(16,924)$ & $(6,396)$ & $(23,852)$ & $(8,543)$ & $(4,790)$ & $\begin{array}{c}(18,660) \\
8,2 \%\end{array}$ \\
\hline & & & $89.4 \%$ & $10.6 \%$ & $56.6 \%$ & $7.3 \%$ & $0.9 \%$ & $14.2 \%$ & $1.7 \%$ & $0.5 \%$ & $8.2 \%$ \\
\hline & 2016 & $22,770,361$ & $\begin{array}{c}20,632,784 \\
(20,063)\end{array}$ & $\begin{array}{c}2,137,577 \\
(20,063)\end{array}$ & $\begin{array}{c}12,943,081 \\
(36,223)\end{array}$ & $\begin{array}{c}1,693,985 \\
(18,674)\end{array}$ & $\begin{array}{c}195,914 \\
(6,676)\end{array}$ & $\begin{array}{c}3,415,042 \\
(27,140)\end{array}$ & $\begin{array}{c}378,102 \\
(8,664)\end{array}$ & $\begin{array}{c}106,092 \\
(4,247)\end{array}$ & $\begin{array}{c}1,900,567 \\
(16,688)\end{array}$ \\
\hline & & & $90.6 \%$ & $9.4 \%$ & $56.8 \%$ & $7.4 \%$ & $0.9 \%$ & $15.0 \%$ & $1.7 \%$ & $0.5 \%$ & $8.3 \%$ \\
\hline & 2017 & $22,764,726$ & $20,613,557$ & $2,151,169$ & $13,045,964$ & $1,575,986$ & 189,218 & $3,446,529$ & 376,991 & 108,827 & $1,870,040$ \\
\hline & & & $(21,258)$ & $(21,258)$ & $(41,855)$ & $(20,395)$ & $(6,918)$ & $(25,481)$ & $(7,997)$ & $(3,879)$ & $(16,277)$ \\
\hline & & & $90.6 \%$ & $9.4 \%$ & $57.3 \%$ & $6.9 \%$ & $0.8 \%$ & $15.1 \%$ & $1.7 \%$ & $0.5 \%$ & $8.2 \%$ \\
\hline \multirow{16}{*}{$\begin{array}{c}<138 \% \text { FPL (or } \\
\text { missing) }\end{array}$} & 2012 & $5,623,770$ & $\begin{array}{c}3,486,137 \\
(15,3877\end{array}$ & 2,137,633 & 1,090,955 & 266,930 & 37,225 & 1,312,116 & 158,833 & 54,192 & $\begin{array}{l}565,886 \\
(10171)\end{array}$ \\
\hline & & & $62.0 \%$ & $38.0 \%$ & $19.4 \%$ & $\begin{array}{c}(6,339) \\
4.7 \%\end{array}$ & $\begin{array}{c}(2,250) \\
0.7 \%\end{array}$ & $\begin{array}{c}(13,394) \\
23.3 \%\end{array}$ & $\begin{array}{c}(5,5 / 2) \\
2.8 \%\end{array}$ & $\begin{array}{c}(2,715) \\
1.0 \%\end{array}$ & $\begin{array}{c}(10,171) \\
10.1 \%\end{array}$ \\
\hline & 2013 & $5,614,596$ & $3,565,434$ & $2,049,162$ & $1,099,141$ & 295,350 & 35,780 & $1,403,359$ & 152,771 & 49,542 & 529,491 \\
\hline & & & $(14,196)$ & $(14,196)$ & $(14,619)$ & $(6,230)$ & $(2,751)$ & $(14,513)$ & $(4,864)$ & $(2,832)$ & $(10,279)$ \\
\hline & & & $63.5 \%$ & $36.5 \%$ & $19.6 \%$ & $5.3 \%$ & $0.6 \%$ & $25.0 \%$ & $2.7 \%$ & $0.9 \%$ & $9.4 \%$ \\
\hline & 2014 & $5,508,264$ & $4,063,643$ & $1,444,621$ & $1,094,395$ & 345,795 & 36,913 & $1,796,167$ & 170,737 & 45,139 & 574,497 \\
\hline & & & $(14,482)$ & $(14,482)$ & $(14,752)$ & $(8,844)$ & $(3,194)$ & $(14,367)$ & $(5,695)$ & $(2,576)$ & $(8,947)$ \\
\hline & & & $73.8 \%$ & $26.2 \%$ & $19.9 \%$ & $6.3 \%$ & $0.7 \%$ & $32.6 \%$ & $3.1 \%$ & $0.8 \%$ & $10.4 \%$ \\
\hline & 2015 & $5,365,608$ & $4,356,251$ & $1,009,357$ & $1,022,556$ & 347,018 & 30,246 & $2,142,545$ & 167,561 & 36,519 & 609,806 \\
\hline & & & $(13,443)$ & $(13,443)$ & $(12,108)$ & $(8,771)$ & $(2,412)$ & $(17,824)$ & $(5,805)$ & $(2,519)$ & $(10,135)$ \\
\hline & & & $81.2 \%$ & $18.8 \%$ & $19.1 \%$ & $6.5 \%$ & $0.6 \%$ & $39.9 \%$ & $3.1 \%$ & $0.7 \%$ & $11.4 \%$ \\
\hline & 2016 & $5,201,206$ & $\begin{array}{c}4,321,325 \\
(14,569)\end{array}$ & $\begin{array}{l}879,881 \\
(14,569)\end{array}$ & $\begin{array}{l}993,119 \\
(13,680)\end{array}$ & $\begin{array}{c}345,588 \\
(7,288)\end{array}$ & $\begin{array}{l}35,697 \\
(3,113)\end{array}$ & $\begin{array}{c}2,165,387 \\
(16,750)\end{array}$ & $\begin{array}{c}161,572 \\
(5,395)\end{array}$ & $\begin{array}{l}31,557 \\
(2,505)\end{array}$ & $\begin{array}{l}588,405 \\
(10,180)\end{array}$ \\
\hline & & & $83.1 \%$ & $16.9 \%$ & $19.1 \%$ & $6.6 \%$ & $0.7 \%$ & $41.6 \%$ & $3.1 \%$ & $0.6 \%$ & $11.3 \%$ \\
\hline & 2017 & $5,024,634$ & $4,187,283$ & 837,351 & 917,624 & 303,886 & 27,672 & 2,159,666 & 160,896 & 32,994 & 584,545 \\
\hline & & & $(11,749)$ & $(11,749)$ & $(12,272)$ & $(8,257)$ & $(1,969)$ & $(18,316)$ & $(5,733)$ & $(2,232)$ & $(10,140)$ \\
\hline & & & $83.3 \%$ & $16.7 \%$ & $18.3 \%$ & $6.0 \%$ & $0.6 \%$ & $43.0 \%$ & $3.2 \%$ & $0.7 \%$ & $11.6 \%$ \\
\hline \multirow[t]{9}{*}{ 138\%-249\% FPL } & 2012 & $4,266,176$ & $3,067,751$ & $1,198,425$ & 1,962,182 & 239,058 & 43,018 & 305,727 & 105,314 & 42,375 & 370,077 \\
\hline & & & $(13,293)$ & $(13,293)$ & $(15,908)$ & $(6,345)$ & $(3,362)$ & $(8,296)$ & $(3,915)$ & $(2,675)$ & $(8,528)$ \\
\hline & & & $71.9 \%$ & $28.1 \%$ & $46.0 \%$ & $5.6 \%$ & $1.0 \%$ & $7.2 \%$ & $2.5 \%$ & $1.0 \%$ & $8.7 \%$ \\
\hline & 2013 & 4,332,888 & $3,147,580$ & $1,185,308$ & $2,034,852$ & 238,936 & 39,311 & 327,046 & 108,712 & 39,711 & 359,012 \\
\hline & & & $(13,449)$ & $(13,449)$ & $(16,179)$ & $(6,405)$ & $(2,953)$ & $(7,459)$ & $(4,637)$ & $(2,527)$ & $(7,994)$ \\
\hline & & & $72.6 \%$ & $27.4 \%$ & $47.0 \%$ & $5.5 \%$ & $0.9 \%$ & $7.5 \%$ & $2.5 \%$ & $0.9 \%$ & $8.3 \%$ \\
\hline & 2014 & 4,428,554 & $3,531,693$ & 896,861 & $2,117,241$ & 341,320 & 37,253 & 501,347 & 118,209 & 36,599 & 379,724 \\
\hline & & & $(11,840)$ & $(11,840)$ & $(16,865)$ & $(7,393)$ & $(2,550)$ & $(9,935)$ & $(4,467)$ & $(2,519)$ & $(8,156)$ \\
\hline & & & 79.7\% & $20.3 \%$ & $47.8 \%$ & $7.7 \%$ & $0.8 \%$ & $11.3 \%$ & $2.7 \%$ & $0.8 \%$ & $8.6 \%$ \\
\hline
\end{tabular}




\begin{tabular}{|c|c|c|c|c|c|c|c|c|c|c|c|}
\hline & 2015 & $4,287,873$ & $\begin{array}{c}3,619,892 \\
(10,544)\end{array}$ & $\begin{array}{l}667,981 \\
(10,544)\end{array}$ & $\begin{array}{c}1,997,111 \\
(15,456)\end{array}$ & $\begin{array}{c}366,294 \\
(6,840)\end{array}$ & $\begin{array}{l}39,780 \\
(3,014)\end{array}$ & $\begin{array}{l}667,695 \\
(11,089)\end{array}$ & $\begin{array}{c}115,016 \\
(4,236)\end{array}$ & $\begin{array}{l}32,448 \\
(2,139)\end{array}$ & $\begin{array}{l}401,548 \\
(8,274)\end{array}$ \\
\hline & & & $84.4 \%$ & $15.6 \%$ & $46.6 \%$ & $8.5 \%$ & $0.9 \%$ & $15.6 \%$ & $2.7 \%$ & $0.8 \%$ & $9.4 \%$ \\
\hline & 2016 & $4,186,655$ & $\begin{array}{c}3,596,347 \\
(9,840)\end{array}$ & $\begin{array}{c}590,308 \\
(9,840)\end{array}$ & $\begin{array}{c}1,926,423 \\
(14,595)\end{array}$ & $\begin{array}{c}359,789 \\
(8,597)\end{array}$ & $\begin{array}{l}34,292 \\
(2,744)\end{array}$ & $\begin{array}{l}731,500 \\
(12,840)\end{array}$ & $\begin{array}{c}114,543 \\
(5,164)\end{array}$ & $\begin{array}{l}29,247 \\
(2,560)\end{array}$ & $\begin{array}{c}400,553 \\
(7,873)\end{array}$ \\
\hline & & & $85.9 \%$ & $14.1 \%$ & $46.0 \%$ & $8.6 \%$ & $0.8 \%$ & $17.5 \%$ & $2.7 \%$ & $0.7 \%$ & $9.6 \%$ \\
\hline & 2017 & $4,175,478$ & $\begin{array}{c}3,573,777 \\
(9,922)\end{array}$ & $\begin{array}{l}601,701 \\
(9,922)\end{array}$ & $\begin{array}{c}1,930,603 \\
(16,943)\end{array}$ & $\begin{array}{c}335,983 \\
(7,616)\end{array}$ & $\begin{array}{l}30,252 \\
(2,493)\end{array}$ & $\begin{array}{l}746,776 \\
(11,941)\end{array}$ & $\begin{array}{c}118,114 \\
(4,373)\end{array}$ & $\begin{array}{l}25,374 \\
(2,096)\end{array}$ & $\begin{array}{r}386,675 \\
(8,672)\end{array}$ \\
\hline & & & $\begin{array}{l}(9,922) \\
85.6 \%\end{array}$ & $14.4 \%$ & $46.2 \%$ & $\begin{array}{c}(7,010) \\
8.0 \%\end{array}$ & $\begin{array}{c}(2,450) \\
0.7 \%\end{array}$ & $\begin{array}{c}(11,941) \\
17.9 \%\end{array}$ & $\begin{array}{c}(4,3 / 3) \\
2.8 \%\end{array}$ & $\begin{array}{c}(2,096) \\
0.6 \%\end{array}$ & $\begin{array}{c}(8,672) \\
9.3 \%\end{array}$ \\
\hline \multirow[t]{17}{*}{$\geq 250 \% \mathrm{FPL}$} & 2012 & $12,956,172$ & $11,765,835$ & $1,190,337$ & $9,659,092$ & 739,141 & 137,141 & 184,261 & 80,790 & 51,821 & 913,589 \\
\hline & & & $(16,846)$ & $(16,846)$ & $(24,820)$ & $(13,486)$ & $(5,949)$ & $(6,860)$ & $(4,178)$ & $(2,834)$ & $(13,480)$ \\
\hline & & & $90.8 \%$ & $9.2 \%$ & $74.6 \%$ & $5.7 \%$ & $1.1 \%$ & $1.4 \%$ & $0.6 \%$ & $0.4 \%$ & $7.1 \%$ \\
\hline & 2013 & $12,886,495$ & $11,707,879$ & $1,178,616$ & $9,611,392$ & 774,070 & 129,551 & 187,599 & 94,035 & 51,674 & 859,560 \\
\hline & & & $(13,515)$ & $(13,515)$ & $(21,966)$ & $(12,325)$ & $(5,713)$ & $(6,091)$ & $(3,572)$ & $(3,369)$ & $(11,349)$ \\
\hline & & & $90.9 \%$ & $9.1 \%$ & $74.6 \%$ & $6.0 \%$ & $1.0 \%$ & $1.5 \%$ & $0.7 \%$ & $0.4 \%$ & $6.7 \%$ \\
\hline & 2014 & $12,898,128$ & $11,993,630$ & 904,498 & $9,756,773$ & 853,129 & 118,948 & 306,047 & 92,621 & 53,464 & 812,648 \\
\hline & & & $(15,447)$ & $(15,447)$ & $(25,601)$ & $(12,387)$ & $(4,215)$ & $(7,045)$ & $(3,857)$ & $(3,130)$ & $(10,049)$ \\
\hline & & & $93.0 \%$ & $7.0 \%$ & $75.6 \%$ & $6.6 \%$ & $0.9 \%$ & $2.4 \%$ & $0.7 \%$ & $0.4 \%$ & $6.3 \%$ \\
\hline & 2015 & $13,158,055$ & $12,427,245$ & 730,810 & $9,885,884$ & 961,724 & $\begin{array}{l}124,324 \\
(5,397)\end{array}$ & 434,383 & 106,353 & 46,930 & 867,649 \\
\hline & & & $94.4 \%$ & $5.6 \%$ & $75.1 \%$ & $7.3 \%$ & $0.9 \%$ & & $0.8 \%$ & $\begin{array}{c}(3,340) \\
0.4 \%\end{array}$ & $\begin{array}{c}(11,844) \\
6.6 \%\end{array}$ \\
\hline & 2016 & $13,382,500$ & $12,715,113$ & 667,387 & $10,023,539$ & 988,609 & 125,927 & 518,154 & 101,987 & 45,288 & 911,609 \\
\hline & & & $(13,215)$ & $(13,215)$ & $(22,764)$ & $(14,717)$ & $(5,519)$ & $(12,596)$ & $(4,375)$ & $(2,531)$ & $(12,055)$ \\
\hline & & & $95.0 \%$ & $5.0 \%$ & $74.9 \%$ & $7.4 \%$ & $0.9 \%$ & $3.9 \%$ & $0.8 \%$ & $0.3 \%$ & $6.8 \%$ \\
\hline & 2017 & $13,564,614$ & $12,852,498$ & 712,116 & $10,197,737$ & 936,118 & 131,295 & 540,089 & 97,981 & 50,459 & 898,821 \\
\hline & & & $(13,548)$ & $(13,548)$ & $(26,827)$ & $(15,384)$ & $(6,081)$ & $(10,925)$ & $(3,677)$ & $(2,887)$ & $(12,778)$ \\
\hline & & & $94.8 \%$ & $5.2 \%$ & $75.2 \%$ & $6.9 \%$ & $1.0 \%$ & $4.0 \%$ & $0.7 \%$ & $0.4 \%$ & $6.6 \%$ \\
\hline
\end{tabular}

Source: Authors’ tabulation of the 2012-2017 American Community Survey data for working-age adults aged 19-64.

Notes: Individuals reporting more than one source of coverage are included in the final column. All numbers are weighted using ACS person weight. There are between 218,973 and 223,542

unweighted observations in the 2012-2017 ACS, respectively. Standard errors are in parentheses and computed using ACS replicate weights. Approximately 3\% of adults did not have a poverty line measure; they are included in the 0-137\% of FPL category. "New expanders” includes 9 states that expanded Medicaid in 2014 but not before: Arkansas, Kentucky, Michigan, Nevada, New Hampshire, New Mexico, North Dakota, Ohio, and West Virginia. 
Table 2: Never Expanders, Coverage for Working-Age Adults

\begin{tabular}{|c|c|c|c|c|c|c|c|c|c|c|c|}
\hline \multirow[b]{2}{*}{ Income bin } & \multirow[b]{2}{*}{ Year } & \multirow[b]{2}{*}{ Population } & \multirow[b]{2}{*}{ Any coverage } & \multirow[b]{2}{*}{ Uninsured } & \multicolumn{3}{|c|}{ Private Sources } & \multicolumn{3}{|c|}{ Public Sources } & \multirow[b]{2}{*}{ Multiple } \\
\hline & & & & & ESHI & Non-group & Tricare & Medicaid & Medicare & VA & \\
\hline \multirow[t]{17}{*}{ All } & 2012 & $55,635,019$ & $\begin{array}{c}40,709,840 \\
(50,033)\end{array}$ & $\begin{array}{c}14,925,179 \\
(50,033)\end{array}$ & $\begin{array}{c}27,376,530 \\
(52,753)\end{array}$ & $\begin{array}{c}3,412,407 \\
(28,457)\end{array}$ & $\begin{array}{c}1,052,882 \\
(15,984)\end{array}$ & $\begin{array}{c}3,349,568 \\
(23,239)\end{array}$ & $\begin{array}{l}750,194 \\
(9,636)\end{array}$ & $\begin{array}{l}385,706 \\
(8,668)\end{array}$ & $\begin{array}{c}4,382,554 \\
(24,090)\end{array}$ \\
\hline & & & $73.2 \%$ & $26.8 \%$ & $49.2 \%$ & $6.1 \%$ & $1.9 \%$ & $6.0 \%$ & $1.3 \%$ & $0.7 \%$ & $7.9 \%$ \\
\hline & 2013 & $55,998,623$ & $41,189,966$ & $14,808,657$ & $27,816,700$ & $3,617,657$ & $1,094,482$ & $3,367,270$ & 787,122 & 363,549 & 4,143,181 \\
\hline & & & $(58,367)$ & $(58,367)$ & $(62,198)$ & $(24,869)$ & $(16,508)$ & $(27,439)$ & $(12,448)$ & $(8,596)$ & $(28,139)$ \\
\hline & & & $73.6 \%$ & $26.4 \%$ & $49.7 \%$ & $6.5 \%$ & $2.0 \%$ & $6.0 \%$ & $1.4 \%$ & $0.6 \%$ & $7.4 \%$ \\
\hline & 2014 & $56,565,140$ & $43,667,078$ & $12,898,062$ & $28,825,375$ & $4,856,881$ & $1,059,742$ & $3,527,730$ & 837,832 & 362,894 & 4,196,624 \\
\hline & & & $(54,778)$ & $(54,778)$ & $(58,907)$ & $(32,214)$ & $(14,645)$ & $(25,901)$ & $(11,217)$ & $(7,936)$ & $(28,039)$ \\
\hline & & & $77.2 \%$ & $22.8 \%$ & $51.0 \%$ & $8.6 \%$ & $1.9 \%$ & $6.2 \%$ & $1.5 \%$ & $0.6 \%$ & $7.4 \%$ \\
\hline & 2015 & $57,119,240$ & $45,705,274$ & $11,413,966$ & $29,652,814$ & $5,795,369$ & $1,073,413$ & $3,670,208$ & 843,600 & 345,017 & $4,324,846$ \\
\hline & & & $(44,433)$ & $(44,433)$ & $(56,714)$ & $(31,267)$ & $(16,993)$ & $(25,961)$ & $(11,224)$ & $(9,253)$ & $(25,921)$ \\
\hline & & & $80.0 \%$ & $20.0 \%$ & $51.9 \%$ & $10.1 \%$ & $1.9 \%$ & $6.4 \%$ & $1.5 \%$ & $0.6 \%$ & $7.6 \%$ \\
\hline & 2016 & $57,486,065$ & $46,533,211$ & $10,952,854$ & $30,147,158$ & $5,900,180$ & $1,052,202$ & $3,746,626$ & 871,908 & 338,294 & 4,476,837 \\
\hline & & & $(40,148)$ & $(40,148)$ & $(51,462)$ & $(33,750)$ & $(14,228)$ & $(33,836)$ & $(12,768)$ & $(8,083)$ & $(28,312)$ \\
\hline & & & $80.9 \%$ & $19.1 \%$ & $52.4 \%$ & $10.3 \%$ & $1.8 \%$ & $6.5 \%$ & $1.5 \%$ & $0.6 \%$ & $7.8 \%$ \\
\hline & 2017 & $58,034,073$ & $46,619,659$ & $11,414,414$ & $30,718,967$ & $5,423,516$ & $1,064,780$ & $3,706,317$ & 875,647 & 335,280 & $4,495,151$ \\
\hline & & & $(51,447)$ & $(51,447)$ & $(62,735)$ & $(38,958)$ & $(13,853)$ & $(27,433)$ & $(12,588)$ & $(8,456)$ & $(28,384)$ \\
\hline & & & $80.3 \%$ & $19.7 \%$ & $52.9 \%$ & $9.3 \%$ & $1.8 \%$ & $6.4 \%$ & $1.5 \%$ & $0.6 \%$ & $7.7 \%$ \\
\hline \multirow{18}{*}{$\begin{array}{l}<138 \% \text { FPL (or } \\
\text { missing) }\end{array}$} & 2012 & $14,374,649$ & $7,427,499$ & $6,947,150$ & $2,482,120$ & 744,420 & 230,398 & $2,296,687$ & 319,132 & 135,437 & $1,219,307$ \\
\hline & & & $(26,950)$ & $(26,950)$ & $(20,247)$ & $(13,689)$ & $(6,273)$ & $(17,214)$ & $(7,466)$ & $(5,199)$ & $(14,263)$ \\
\hline & & & $51.7 \%$ & $48.3 \%$ & $17.3 \%$ & $5.2 \%$ & $1.6 \%$ & $16.0 \%$ & $2.2 \%$ & $0.9 \%$ & $8.5 \%$ \\
\hline & 2013 & $14,253,377$ & $7,476,924$ & $6,776,453$ & $2,564,616$ & 798,858 & 239,765 & $2,272,089$ & 341,919 & 126,681 & $1,132,995$ \\
\hline & & & $(28,671)$ & $(28,671)$ & $(21,295)$ & $(10,881)$ & $(7,028)$ & $(20,539)$ & $(8,407)$ & $(4,761)$ & $(13,203)$ \\
\hline & & & $52.5 \%$ & $47.5 \%$ & $18.0 \%$ & $5.6 \%$ & $1.7 \%$ & $15.9 \%$ & $2.4 \%$ & $0.9 \%$ & $7.9 \%$ \\
\hline & 2014 & $14,031,179$ & $8,052,753$ & $5,978,426$ & $2,687,855$ & $1,113,416$ & 219,867 & $2,329,305$ & 356,156 & 121,445 & $1,224,709$ \\
\hline & & & $(32,618)$ & $(32,618)$ & $(22,255)$ & $(15,067)$ & $(6,513)$ & $(20,978)$ & $(7,498)$ & $(4,750)$ & $(12,977)$ \\
\hline & & & $57.4 \%$ & $42.6 \%$ & $19.2 \%$ & $7.9 \%$ & $1.6 \%$ & $16.6 \%$ & $2.5 \%$ & $0.9 \%$ & $8.7 \%$ \\
\hline & 2015 & $13,622,028$ & $8,309,675$ & $5,312,353$ & $2,696,228$ & $1,342,915$ & 215,844 & $2,363,173$ & 356,172 & 112,507 & $1,222,834$ \\
\hline & & & $(23,498)$ & $(23,498)$ & $(20,658)$ & $(16,138)$ & $(5,427)$ & $(19,358)$ & $(8,181)$ & $(4,062)$ & $(12,510)$ \\
\hline & & & $61.0 \%$ & $39.0 \%$ & $19.8 \%$ & $9.9 \%$ & $1.6 \%$ & $17.3 \%$ & $2.6 \%$ & $0.8 \%$ & $9.0 \%$ \\
\hline & 2016 & $13,171,371$ & $8,238,949$ & $4,932,422$ & $2,700,006$ & $1,323,627$ & 215,805 & $2,320,541$ & 355,719 & 105,054 & $1,218,196$ \\
\hline & & & $(24,439)$ & $(24,439)$ & $(20,777)$ & $(14,070)$ & $(5,627)$ & $(23,577)$ & $(8,593)$ & $(4,119)$ & $(14,093)$ \\
\hline & & & $62.6 \%$ & $37.4 \%$ & $20.5 \%$ & $10.0 \%$ & $1.6 \%$ & $17.6 \%$ & $2.7 \%$ & $0.8 \%$ & $9.2 \%$ \\
\hline & 2017 & $12,761,687$ & $7,903,956$ & $4,857,731$ & $2,558,115$ & $1,179,932$ & 219,028 & $2,275,268$ & 349,170 & 97,812 & $1,224,631$ \\
\hline & & & $(23,081)$ & $(23,081)$ & $(19,889)$ & $(15,571)$ & $(5,818)$ & $(19,745)$ & $(7,175)$ & $(3,891)$ & $(14,140)$ \\
\hline & & & $61.9 \%$ & $38.1 \%$ & $20.0 \%$ & $9.2 \%$ & $1.7 \%$ & $17.8 \%$ & $2.7 \%$ & $0.8 \%$ & $9.6 \%$ \\
\hline \multirow[t]{9}{*}{$138 \%-249 \%$ FPL } & 2012 & $11,165,078$ & $7,116,303$ & $4,048,775$ & $4,446,949$ & 609,411 & 192,318 & 662,318 & 238,980 & 104,560 & 861,766 \\
\hline & & & $(22,799)$ & $(22,799)$ & $(23,266)$ & $(10,769)$ & $(7,634)$ & $(10,739)$ & $(5,776)$ & $(5,044)$ & $(12,647)$ \\
\hline & & & $63.7 \%$ & $36.3 \%$ & $39.8 \%$ & $5.5 \%$ & $1.7 \%$ & $5.9 \%$ & $2.1 \%$ & $0.9 \%$ & $7.7 \%$ \\
\hline & 2013 & $11,417,744$ & $7,340,073$ & $4,077,671$ & $4,647,329$ & 659,775 & 211,087 & 671,135 & 236,606 & 92,783 & 821,355 \\
\hline & & & $(25,504)$ & $(25,504)$ & $(23,514)$ & $(11,793)$ & $(6,520)$ & $(12,834)$ & $(6,835)$ & $(3,682)$ & $(12,505)$ \\
\hline & & & $64.3 \%$ & $35.7 \%$ & $40.7 \%$ & $5.8 \%$ & $1.8 \%$ & $5.9 \%$ & $2.1 \%$ & $0.8 \%$ & $7.2 \%$ \\
\hline & 2014 & $11,675,999$ & $8,108,375$ & $3,567,624$ & $4,895,215$ & $1,046,697$ & 204,733 & 740,483 & 258,411 & 95,480 & 867,355 \\
\hline & & & $(24,876)$ & $(24,876)$ & $(22,748)$ & $(16,582)$ & $(5,984)$ & $(11,368)$ & $(6,855)$ & $(5,072)$ & $(12,274)$ \\
\hline & & & $69.4 \%$ & $30.6 \%$ & $41.9 \%$ & $9.0 \%$ & $1.8 \%$ & $6.3 \%$ & $2.2 \%$ & $0.8 \%$ & $7.4 \%$ \\
\hline
\end{tabular}




\begin{tabular}{|c|c|c|c|c|c|c|c|c|c|c|c|}
\hline & 2015 & $11,595,625$ & $\begin{array}{c}8,493,879 \\
(24,842)\end{array}$ & $\begin{array}{c}3,101,746 \\
(24,842)\end{array}$ & $\begin{array}{c}4,931,573 \\
(22,367)\end{array}$ & $\begin{array}{c}1,365,267 \\
(15,589)\end{array}$ & $\begin{array}{c}204,526 \\
(6,570)\end{array}$ & $\begin{array}{c}774,828 \\
(12,280)\end{array}$ & $\begin{array}{c}243,285 \\
(5,721)\end{array}$ & $\begin{array}{l}91,190 \\
(4,671)\end{array}$ & $\begin{array}{l}883,210 \\
(12,542)\end{array}$ \\
\hline & & & $73.3 \%$ & $26.7 \%$ & $42.5 \%$ & $11.8 \%$ & $1.8 \%$ & $6.7 \%$ & $2.1 \%$ & $0.8 \%$ & $7.6 \%$ \\
\hline & 2016 & $11,458,342$ & $\begin{array}{c}8,487,632 \\
(22,384)\end{array}$ & $\begin{array}{c}2,970,710 \\
(22,384)\end{array}$ & $\begin{array}{c}4,832,866 \\
(23,838)\end{array}$ & $\begin{array}{c}1,357,962 \\
(18,396)\end{array}$ & $\begin{array}{c}196,185 \\
(7,021)\end{array}$ & $\begin{array}{l}834,637 \\
(14,264)\end{array}$ & $\begin{array}{c}249,681 \\
(6,412)\end{array}$ & $\begin{array}{l}84,040 \\
(4,612)\end{array}$ & $\begin{array}{l}932,260 \\
(12,493)\end{array}$ \\
\hline & & & $74.1 \%$ & $25.9 \%$ & $42.2 \%$ & $11.9 \%$ & $1.7 \%$ & $7.3 \%$ & $2.2 \%$ & $0.7 \%$ & $8.1 \%$ \\
\hline & 2017 & $11,544,025$ & $\begin{array}{c}8,436,219 \\
(26,727)\end{array}$ & $\begin{array}{c}3,107,806 \\
(26,727)\end{array}$ & $\begin{array}{c}4,889,265 \\
(26,981)\end{array}$ & $\begin{array}{c}1,264,765 \\
(18,074)\end{array}$ & $\begin{array}{c}200,738 \\
(7,277)\end{array}$ & $\begin{array}{l}814,830 \\
(12,857)\end{array}$ & $\begin{array}{c}266,724 \\
(6,676)\end{array}$ & $\begin{array}{l}88,149 \\
(4,305)\end{array}$ & $\begin{array}{l}911,751 \\
(13,120)\end{array}$ \\
\hline & & & $73.1 \%$ & $26.9 \%$ & $42.4 \%$ & $11.0 \%$ & $1.7 \%$ & $7.1 \%$ & $2.3 \%$ & $0.8 \%$ & $7.9 \%$ \\
\hline \multirow[t]{16}{*}{$\geq 250 \% \mathrm{FPL}$} & 2012 & $30,095,292$ & $\begin{array}{c}26,166,036 \\
(30,730)\end{array}$ & $\begin{array}{c}3,929,256 \\
(30,730)\end{array}$ & $\begin{array}{c}20,447,461 \\
(38,170)\end{array}$ & $\begin{array}{c}2,058,578 \\
(20,004)\end{array}$ & $\begin{array}{l}630,162 \\
(13,278)\end{array}$ & $\begin{array}{l}390,562 \\
(7,894)\end{array}$ & $\begin{array}{c}192,083 \\
(5,784)\end{array}$ & $\begin{array}{c}145,712 \\
(5,291)\end{array}$ & $\begin{array}{c}2,301,480 \\
(18,479)\end{array}$ \\
\hline & & & $86.9 \%$ & $13.1 \%$ & $67.9 \%$ & $6.8 \%$ & $2.1 \%$ & $1.3 \%$ & $0.6 \%$ & $0.5 \%$ & $7.6 \%$ \\
\hline & 2013 & $30,327,502$ & $26,372,969$ & $3,954,533$ & $20,604,757$ & $2,159,024$ & 643,631 & 424,042 & 208,599 & 144,086 & $2,188,830$ \\
\hline & & & $(27,595)$ & $(27,595)$ & $(37,837)$ & $(19,234)$ & $(12,219)$ & $(11,060)$ & $(6,317)$ & $(5,410)$ & $(20,137)$ \\
\hline & & & $87.0 \%$ & $13.0 \%$ & $67.9 \%$ & $7.1 \%$ & $2.1 \%$ & $1.4 \%$ & $0.7 \%$ & $0.5 \%$ & $7.2 \%$ \\
\hline & 2014 & $30,857,962$ & $27,505,951$ & $3,352,011$ & $21,242,306$ & $2,696,767$ & 635,143 & 457,944 & 223,264 & 145,967 & $2,104,559$ \\
\hline & & & $(29,281)$ & $(29,281)$ & $(38,551)$ & $(23,594)$ & $(10,482)$ & $(8,930)$ & $(6,459)$ & $(5,033)$ & $(20,601)$ \\
\hline & & & $89.1 \%$ & $10.9 \%$ & $68.8 \%$ & $8.7 \%$ & $2.1 \%$ & $1.5 \%$ & $0.7 \%$ & $0.5 \%$ & $6.8 \%$ \\
\hline & 2015 & $31,901,587$ & $\begin{array}{c}28,901,715 \\
(24,529)\end{array}$ & $\begin{array}{c}2,999,872 \\
(24,529)\end{array}$ & $22,025,009$ & $\begin{array}{l}3,087,190 \\
\end{array}$ & $\begin{array}{l}653,045 \\
(13750)\end{array}$ & 532,208 & 244,143 & $\begin{array}{l}141,324 \\
(5,99)\end{array}$ & $2,218,800$ \\
\hline & & & $\begin{array}{c}(24,529) \\
90.6 \%\end{array}$ & $\begin{array}{c}(24,529) \\
9.4 \%\end{array}$ & $\begin{array}{c}(35,542) \\
69.0 \%\end{array}$ & $\begin{array}{c}(23,706) \\
9.7 \%\end{array}$ & $\begin{array}{c}(13,750) \\
2.0 \%\end{array}$ & $\begin{array}{c}(10,212) \\
1.7 \%\end{array}$ & $\begin{array}{c}(6,626) \\
0.8 \%\end{array}$ & $\begin{array}{c}(5,299) \\
0.4 \%\end{array}$ & $\begin{array}{c}(18,624) \\
7.0 \%\end{array}$ \\
\hline & 2016 & $32,856,352$ & $29,806,625$ & $3,049,727$ & $22,614,288$ & $3,218,589$ & 640,213 & 591,450 & 266,504 & 149,201 & $2,326,381$ \\
\hline & & & $(25,099)$ & $(25,099)$ & $(39,368)$ & $(26,387)$ & $(12,315)$ & $(11,194)$ & $(7,435)$ & $(5,030)$ & $(18,465)$ \\
\hline & & & $90.7 \%$ & $9.3 \%$ & $68.8 \%$ & $9.8 \%$ & $1.9 \%$ & $1.8 \%$ & $0.8 \%$ & $0.5 \%$ & $7.1 \%$ \\
\hline & 2017 & $33,728,361$ & $30,279,484$ & $3,448,877$ & $23,271,588$ & $2,978,818$ & 645,018 & 616,217 & 259,756 & 149,319 & $2,358,769$ \\
\hline & & & $(31,974)$ & $(31,974)$ & $(45,614)$ & $(28,231)$ & $(11,623)$ & $(13,249)$ & $(6,881)$ & $(5,950)$ & $(21,444)$ \\
\hline & & & $89.8 \%$ & $10.2 \%$ & $69.0 \%$ & $8.8 \%$ & $1.9 \%$ & $1.8 \%$ & $0.8 \%$ & $0.4 \%$ & $7.0 \%$ \\
\hline
\end{tabular}

Source: Authors' tabulation of the 2012-2017 American Community Survey data for adults aged 19-64.

Notes: Individuals reporting more than one source of coverage are included in the final column. All numbers are weighted using ACS person weight. There are between 530,103 and 542,848

unweighted observations in the 2012-2017 ACS, respectively. Standard errors are in parentheses and computed using ACS replicate weights. Approximately 3\% of adults did not have a poverty line measure; they are included in the 0-137\% of FPL category. "Never expanders” includes 12 states that had not expanded Medicaid by 2019: Alabama, Florida, Georgia, Kansas, Mississippi, Missouri, North Carolina, Oklahoma, South Carolina, South Dakota, Texas, and Wyoming. 
Table 3: Medicaid-Only Take-Up Among Working-Age Adults

\begin{tabular}{|c|c|c|c|c|c|c|c|c|}
\hline \multirow[b]{3}{*}{ Full Sample } & \multicolumn{2}{|c|}{ Income $<138 \% \mathrm{FPL}$} & \multicolumn{2}{|c|}{ Income $\geq 138 \% \mathrm{FPL}$} & \multicolumn{2}{|c|}{$\begin{array}{l}\text { Income between } \\
138 \%-249 \% \text { FPL }\end{array}$} & \multicolumn{2}{|c|}{ Income $\geq 250 \% \mathrm{FPL}$} \\
\hline & (1) & \multirow[t]{2}{*}{$(2)$} & \multirow[t]{2}{*}{ (3) } & \multirow[t]{2}{*}{ (4) } & \multirow[t]{2}{*}{ (5) } & \multirow[t]{2}{*}{ (6) } & \multirow[t]{2}{*}{$(7)$} & \multirow[t]{2}{*}{ (8) } \\
\hline & (2) & & & & & & & \\
\hline POST*EXPAN & $\begin{array}{c}0.136 * * * \\
(0.017)\end{array}$ & $\begin{array}{c}0.137 * * * \\
(0.017)\end{array}$ & $\begin{array}{c}0.030^{* * *} \\
(0.004)\end{array}$ & $\begin{array}{c}0.030^{* * *} \\
(0.004)\end{array}$ & $\begin{array}{c}0.072 * * * \\
(0.007)\end{array}$ & $\begin{array}{c}0.072 * * * \\
(0.007)\end{array}$ & $\begin{array}{c}0.016^{* * *} \\
(0.002)\end{array}$ & $\begin{array}{c}0.017^{* * * *} \\
(0.002)\end{array}$ \\
\hline EXPAN & $\begin{array}{c}0.082 * * * \\
(0.022)\end{array}$ & --- & $\begin{array}{c}0.003 \\
(0.003)\end{array}$ & --- & $\begin{array}{l}0.015^{*} \\
(0.007)\end{array}$ & --- & $\begin{array}{c}0.001 \\
(0.002)\end{array}$ & -- \\
\hline POST & $\begin{array}{c}0.014 * * * \\
(0.005)\end{array}$ & --- & $\begin{array}{c}0.005^{* * *} \\
(0.001)\end{array}$ & --- & $\begin{array}{c}0.009 * * * \\
(0.003)\end{array}$ & --- & $\begin{array}{c}0.004^{* * *} \\
(0.001)\end{array}$ & --- \\
\hline$R^{2}$ & 0.0435 & 0.1947 & 0.0054 & 0.1223 & 0.0157 & 0.1313 & 0.0029 & 0.1041 \\
\hline $\mathrm{N}$ & \multicolumn{2}{|c|}{$1,094,667$} & \multicolumn{2}{|c|}{$3,440,670$} & \multicolumn{2}{|c|}{833,817} & \multicolumn{2}{|c|}{$2,606,853$} \\
\hline $\begin{array}{l}\text { Mean of dependent variable } \\
\text { (pre-treatment) } \\
\text { Exclude categorically eligible }\end{array}$ & \multicolumn{2}{|c|}{0.182} & \multicolumn{2}{|c|}{0.027} & \multicolumn{2}{|c|}{0.063} & \multicolumn{2}{|c|}{0.014} \\
\hline POST*EXPAN & $\begin{array}{c}0.154^{* * *} \\
(0.021)\end{array}$ & $\begin{array}{c}0.154^{* * *} \\
(0.021)\end{array}$ & $\begin{array}{c}0.026^{* * *} \\
(0.003)\end{array}$ & $\begin{array}{c}0.027 * * * \\
(0.003)\end{array}$ & $\begin{array}{c}0.070^{* * *} \\
(0.008)\end{array}$ & $\begin{array}{l}0.071^{* * *} \\
(0.008)\end{array}$ & $\begin{array}{c}0.014^{* * *} \\
(0.002)\end{array}$ & $\begin{array}{c}0.014^{* * *} \\
(0.002)\end{array}$ \\
\hline EXPAN & $\begin{array}{c}0.061 * * \\
(0.024)\end{array}$ & -- & $\begin{array}{c}0.003 \\
(0.003)\end{array}$ & -- & $\begin{array}{c}0.012 \\
(0.007)\end{array}$ & --- & $\begin{array}{c}0.001 \\
(0.001)\end{array}$ & -- \\
\hline POST & $\begin{array}{l}0.016^{* *} \\
(0.006)\end{array}$ & --- & $\begin{array}{c}0.005^{* * *} \\
(0.001)\end{array}$ & --- & $\begin{array}{c}0.012 * * * \\
(0.003)\end{array}$ & --- & $\begin{array}{c}0.003 * * * \\
(0.001)\end{array}$ & --- \\
\hline$R^{2}$ & 0.0521 & 0.1286 & 0.0068 & 0.0371 & 0.0202 & 0.0548 & 0.0037 & 0.0236 \\
\hline $\mathrm{N}$ & \multicolumn{2}{|c|}{729,595} & \multicolumn{2}{|c|}{ 2,906,015 } & \multicolumn{2}{|c|}{641,749} & \multicolumn{2}{|c|}{$2,264,266$} \\
\hline $\begin{array}{l}\text { Mean of dependent variable } \\
\text { (pre-treatment) }\end{array}$ & \multicolumn{2}{|c|}{0.117} & \multicolumn{2}{|c|}{0.014} & \multicolumn{2}{|c|}{0.036} & \multicolumn{2}{|c|}{0.007} \\
\hline $\begin{array}{l}\text { Controls for individual } \\
\text { characteristics? }\end{array}$ & No & Yes & No & Yes & No & Yes & No & Yes \\
\hline Controls for local area effects? & No & Yes & No & Yes & No & Yes & No & Yes \\
\hline Controls for year effects? & No & Yes & No & Yes & No & Yes & No & Yes \\
\hline
\end{tabular}

Notes: Authors' analysis of 2012-2017 American Community Survey from 21 states. The first panel includes all adults aged 19 to 64 . The second panel excludes adults who might be categorically eligible for Medicaid based on the following variables: had baby in previous year, disabled, social security receipt, public assistance receipt, SSI receipt. Specifications with individual characteristics control for respondent's age, sex, education, race/ethnicity, English difficulty, citizenship, foreign-born, marital status, military service, disability, annual hours of work, recent changes (marital status, births, and moves), and income sources (social security, wages, earnings, interest, other income, public assistance, retirement, self-employment or SSI). All specifications include person weights from ACS. Standard errors in parentheses and clustered at state level. $* * *=p<0.01, * *=p<0.05, *=p<0.10$. 
Table 4: Medicaid-Only Take-Up Among Working-Age Adults

\begin{tabular}{|c|c|c|c|c|c|c|c|c|}
\hline \multirow[b]{3}{*}{ Full Sample } & \multicolumn{2}{|c|}{ Income $<138 \% \mathrm{FPL}$} & \multicolumn{2}{|c|}{ Income $\geq 138 \% \mathrm{FPL}$} & \multicolumn{2}{|c|}{$\begin{array}{l}\text { Income between } \\
138 \%-249 \% \text { FPL }\end{array}$} & \multicolumn{2}{|c|}{ Income $\geq 250 \% \mathrm{FPL}$} \\
\hline & $(1)$ & $(2)$ & (3) & $(4)$ & $(5)$ & (6) & $(7)$ & $(8)$ \\
\hline & & & & & & & & \\
\hline $2017 *$ EXPAN & $\begin{array}{c}0.161^{* * *} \\
(0.020)\end{array}$ & $\begin{array}{c}0.159 * * * \\
(0.020)\end{array}$ & $\begin{array}{c}0.037 * * * \\
(0.004)\end{array}$ & $\begin{array}{c}0.038 * * * \\
(0.004)\end{array}$ & $\begin{array}{c}0.092^{* * *} \\
(0.009)\end{array}$ & $\begin{array}{l}0.092^{* * *} \\
(0.009)\end{array}$ & $\begin{array}{c}0.021^{* * *} \\
(0.002)\end{array}$ & $\begin{array}{c}0.022 * * * \\
(0.002)\end{array}$ \\
\hline 2016*EXPAN & $\begin{array}{c}0.150 * * * \\
(0.021)\end{array}$ & $\begin{array}{c}0.150 * * * \\
(0.021)\end{array}$ & $\begin{array}{c}0.035^{* * *} \\
(0.004)\end{array}$ & $\begin{array}{c}0.036^{* * *} \\
(0.004)\end{array}$ & $\begin{array}{c}0.085^{* * *} \\
(0.009)\end{array}$ & $\begin{array}{c}0.086 * * * \\
(0.009)\end{array}$ & $\begin{array}{c}0.020 * * * \\
(0.002)\end{array}$ & $\begin{array}{c}0.021^{* * *} \\
(0.002)\end{array}$ \\
\hline 2015*EXPAN & $\begin{array}{c}0.135^{* * *} \\
(0.019)\end{array}$ & $\begin{array}{c}0.135^{* * *} \\
(0.019)\end{array}$ & $\begin{array}{c}0.029 * * * \\
(0.003)\end{array}$ & $\begin{array}{c}0.030 * * * \\
(0.003)\end{array}$ & $\begin{array}{c}0.072^{* * *} \\
(0.008)\end{array}$ & $\begin{array}{c}0.071^{* * *} \\
(0.008)\end{array}$ & $\begin{array}{l}0.016^{* * *} \\
(0.002)\end{array}$ & $\begin{array}{c}0.016^{* * * *} \\
(0.002)\end{array}$ \\
\hline $2014 *$ EXPAN & $\begin{array}{c}0.070 * * * \\
(0.015)\end{array}$ & $\begin{array}{c}0.070^{* * *} \\
(0.016)\end{array}$ & $\begin{array}{c}0.015^{* * *} \\
(0.003)\end{array}$ & $\begin{array}{c}0.015^{* * *} \\
(0.003)\end{array}$ & $\begin{array}{c}0.033^{* * *} \\
(0.008)\end{array}$ & $\begin{array}{c}0.033^{* * *} \\
(0.008)\end{array}$ & $\begin{array}{c}0.008 * * * \\
(0.002)\end{array}$ & $\begin{array}{c}0.009 * * * \\
(0.002)\end{array}$ \\
\hline 2013*EXPAN & --- & --- & --- & --- & --- & --- & --- & -- \\
\hline $2012 *$ EXPAN & $\begin{array}{c}-0.017 * * * \\
(0.005)\end{array}$ & $\begin{array}{c}-0.018^{* * *} \\
(0.004)\end{array}$ & $\begin{array}{l}-0.001 \\
(0.001)\end{array}$ & $\begin{array}{l}-0.001 \\
(0.001)\end{array}$ & $\begin{array}{l}-0.004^{*} \\
(0.002)\end{array}$ & $\begin{array}{l}-0.004 \\
(0.002)\end{array}$ & $\begin{array}{c}0.001 \\
(0.001)\end{array}$ & $\begin{array}{c}0.000 \\
(0.001)\end{array}$ \\
\hline$R^{2}$ & 0.0454 & 0.1957 & 0.0061 & 0.1227 & 0.0174 & 0.1322 & 0.0034 & 0.1043 \\
\hline $\mathrm{N}$ & \multicolumn{2}{|c|}{$1,094,667$} & \multicolumn{2}{|c|}{$3,440,670$} & \multicolumn{2}{|c|}{833,817} & \multicolumn{2}{|c|}{$2,606,853$} \\
\hline $\begin{array}{l}\text { Mean of dependent variable } \\
\text { (pre-treatment) }\end{array}$ & \multicolumn{2}{|c|}{0.182} & \multicolumn{2}{|c|}{0.027} & \multicolumn{2}{|c|}{0.063} & \multicolumn{2}{|c|}{0.014} \\
\hline $\begin{array}{l}\text { Controls for individual } \\
\text { characteristics? }\end{array}$ & No & Yes & No & Yes & No & Yes & No & Yes \\
\hline Controls for local area effects? & No & Yes & No & Yes & No & Yes & No & Yes \\
\hline Controls for year effects? & No & Yes & No & Yes & No & Yes & No & Yes \\
\hline
\end{tabular}

Notes: Authors' analysis of 2012-2017 American Community Survey from 21 states. The panel includes all adults aged 19 to 64 . Specifications with individual characteristics control for respondent's age, sex, education, race/ethnicity, English difficulty, citizenship, foreign-born, marital status, military service, disability, annual hours of work, recent changes (marital status, births, and moves), and income sources (social security, wages, earnings, interest, other income, public assistance, retirement, self-employment or SSI). All specifications include person weights from ACS. Standard errors in parentheses and clustered at state level. $* * *=\mathrm{p}<0.01,{ }^{* *}=\mathrm{p}<0.05, *=\mathrm{p}<0.10$. 
Table 5: Medicaid-Only Take-Up Among Working-Age Adults (Exclude Categorically Needy)

\begin{tabular}{|c|c|c|c|c|c|c|c|c|}
\hline \multirow[b]{3}{*}{ Full Sample } & \multicolumn{2}{|c|}{ Income $<138 \%$ FPL } & \multicolumn{2}{|c|}{ Income $\geq 138 \% \mathrm{FPL}$} & \multicolumn{2}{|c|}{$\begin{array}{l}\text { Income between } \\
138 \%-249 \% \text { FPL }\end{array}$} & \multicolumn{2}{|c|}{ Income $\geq 250 \% \mathrm{FPL}$} \\
\hline & $(1)$ & $(2)$ & (3) & (4) & (5) & (6) & (7) & (8) \\
\hline & & & & & & & & \\
\hline $2017 *$ EXPAN & $\begin{array}{c}0.182 * * * \\
(0.025)\end{array}$ & $\begin{array}{c}0.179 * * * \\
(0.024)\end{array}$ & $\begin{array}{c}0.033^{* * *} \\
(0.004)\end{array}$ & $\begin{array}{c}0.034^{* * *} \\
(0.004)\end{array}$ & $\begin{array}{l}0.091^{* * *} \\
(0.010)\end{array}$ & $\begin{array}{c}0.091^{* * *} \\
(0.010)\end{array}$ & $\begin{array}{c}0.018^{* * *} \\
(0.002)\end{array}$ & $\begin{array}{c}0.018 * * * \\
(0.002)\end{array}$ \\
\hline 2016*EXPAN & $\begin{array}{l}0.171^{* * *} \\
(0.026)\end{array}$ & $\begin{array}{c}0.171^{* * *} \\
(0.025)\end{array}$ & $\begin{array}{c}0.032 * * * \\
(0.004)\end{array}$ & $\begin{array}{c}0.033^{* * * *} \\
(0.004)\end{array}$ & $\begin{array}{c}0.086 * * * \\
(0.010)\end{array}$ & $\begin{array}{c}0.087 * * * \\
(0.010)\end{array}$ & $\begin{array}{c}0.018^{* * *} \\
(0.002)\end{array}$ & $\begin{array}{c}0.018 * * * \\
(0.002)\end{array}$ \\
\hline 2015*EXPAN & $\begin{array}{c}0.158^{* * *} \\
(0.023)\end{array}$ & $\begin{array}{c}0.159 * * * \\
(0.024)\end{array}$ & $\begin{array}{c}0.025^{* * *} \\
(0.004)\end{array}$ & $\begin{array}{c}0.026 * * * \\
(0.004)\end{array}$ & $\begin{array}{c}0.066 * * * \\
(0.008)\end{array}$ & $\begin{array}{c}0.066^{* * *} \\
(0.008)\end{array}$ & $\begin{array}{c}0.014^{* * *} \\
(0.002)\end{array}$ & $\begin{array}{c}0.015^{* * *} \\
(0.002)\end{array}$ \\
\hline 2014*EXPAN & $\begin{array}{c}0.077 * * * \\
(0.017)\end{array}$ & $\begin{array}{c}0.077 * * * \\
(0.017)\end{array}$ & $\begin{array}{c}0.012 * * * \\
(0.003)\end{array}$ & $\begin{array}{c}0.012 * * * \\
(0.003)\end{array}$ & $\begin{array}{c}0.028 * * * \\
(0.008)\end{array}$ & $\begin{array}{c}0.029 * * * \\
(0.008)\end{array}$ & $\begin{array}{c}0.007 * * * \\
(0.002)\end{array}$ & $\begin{array}{c}0.007 * * * \\
(0.002)\end{array}$ \\
\hline 2013*EXPAN & -- & --- & --- & --- & --- & --- & -- & -- \\
\hline $2012 *$ EXPAN & $\begin{array}{c}-0.017 * * * \\
(0.004)\end{array}$ & $\begin{array}{c}-0.019 * * * \\
(0.004)\end{array}$ & $\begin{array}{l}-0.001 \\
(0.001)\end{array}$ & $\begin{array}{l}-0.001 \\
(0.001)\end{array}$ & $\begin{array}{l}-0.005^{*} \\
(0.003)\end{array}$ & $\begin{array}{l}-0.005 * \\
(0.003)\end{array}$ & $\begin{array}{c}0.000 \\
(0.001)\end{array}$ & $\begin{array}{c}0.000 \\
(0.001)\end{array}$ \\
\hline$R^{2}$ & 0.0552 & 0.1303 & 0.0076 & 0.0376 & 0.0229 & 0.0563 & 0.0042 & 0.0238 \\
\hline $\mathrm{N}$ & \multicolumn{2}{|c|}{729,595} & \multicolumn{2}{|c|}{$2,906,015$} & \multicolumn{2}{|c|}{641,749} & \multicolumn{2}{|c|}{$2,264,266$} \\
\hline $\begin{array}{l}\text { Mean of dependent variable } \\
\text { (pre-treatment) }\end{array}$ & \multicolumn{2}{|c|}{0.117} & \multicolumn{2}{|c|}{0.014} & \multicolumn{2}{|c|}{0.036} & \multicolumn{2}{|c|}{0.007} \\
\hline $\begin{array}{l}\text { Controls for individual } \\
\text { characteristics? }\end{array}$ & No & Yes & No & Yes & No & Yes & No & Yes \\
\hline Controls for local area effects? & No & Yes & No & Yes & No & Yes & No & Yes \\
\hline Controls for year effects? & No & Yes & No & Yes & No & Yes & No & Yes \\
\hline
\end{tabular}



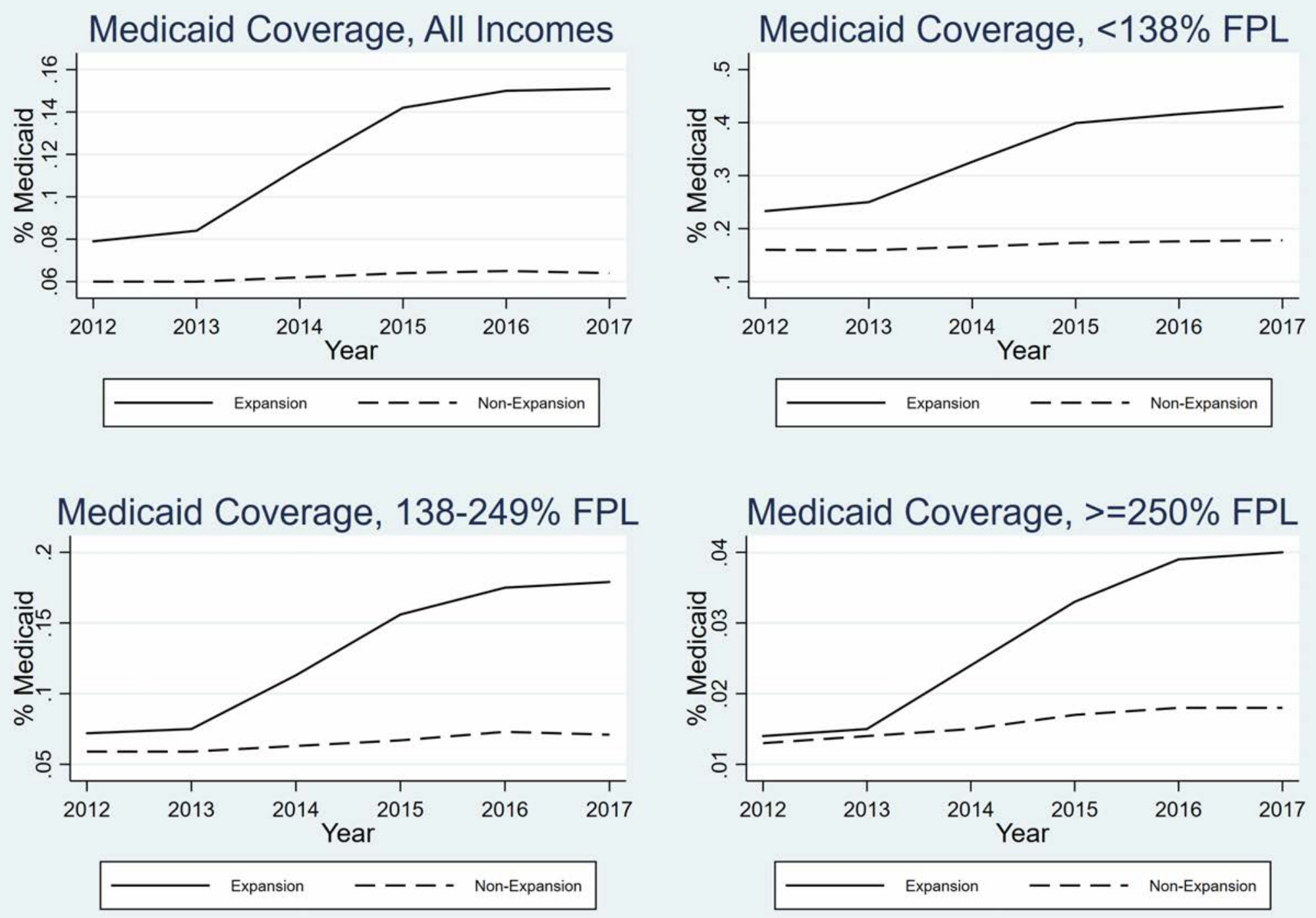